\title{
The Voices of European Law: Legislators, Judges and Law Professors
}

\author{
Arthur Dyevre ${ }^{1}$, Monika Glavina ${ }^{1, \star}$ and Michal Ovádek ${ }^{1}$ \\ ${ }^{1} \mathrm{KU}$ Leuven Centre for Legal Theory and Empirical Jurisprudence, Leuven, Belgium \\ •Corresponding author: monika.glavina@uantwerpen.be
}

(Received 22 October 2020; accepted 14 December 2020)

\begin{abstract}
European Union legislators, CJEU judges and EU law scholars have produced streams of texts which determine both what EU law is and how it is perceived. We explore what these distinct "voices" tell us about the EU's legal and policy priorities using a mega corpus compiling more than 200,000 legislative acts, 55,000 court rulings and opinions, and 4,000 articles from a leading EU law journal. Applying an unsupervised machine learning technique known as probabilistic topic modelling, we find that economic integration remains the focus of EU law, but that scholars tend to emphasize rights issues more and ignore certain topics, such as farming regulations, almost entirely. The relationship among these partly interdependent, partly autonomous voices, we suggest, can be conceptualized in terms of co-evolution. Legislation influences issue attention on the CJEU, which, in turn, influences what law professors choose to write about.
\end{abstract}

Keywords: Topic Modelling; issue attention; EU law; co-evolution; CJEU

\section{A. Introduction}

Anecdotal observation suggests that what legal scholars and law students know about EU law is principally shaped by what they read in textbooks, law review articles, and, occasionally, the odd directive or regulation - when these happen to involve their main area of interest. Of course, nobody can read the massive number of texts generated by EU legislators, judges, and legal scholars. Over its lifetime, the EU has produced more than 200,000 legislative acts. If advisory and Advocate General opinions are included, the CJEU has issued more than 55,000 documents. Legal scholars, in the meantime, have churned out tens of thousands of articles and case notes along with textbooks and commentaries.

So, however voracious a reader, what one manages to read can only paint an incomplete and fragmented picture of all the issues that EU law embraces and prioritizes. Yet, despite the cognitive challenge posed by the sheer mass of textual information, statements about the substantive focus of EU law or alleged inflections abound: The Maastricht Treaty allegedly marked an inflection

Arthur Dyevre is Professor at KU Leuven and researcher at the Centre for Empirical Jurisprudence.

Monika Glavina is a postdoctoral researcher at the University of Antwerp, associated with the GOVTRUST Centre of Excellence: research group Politics and Public Governance (Faculty of Social Sciences) and research group Government and Law (Faculty of Law).

Michal Ovádek is a postdoctoral research fellow at the Department of Political Science, University of Gothenburg.

(C) The Author(s) 2021. Published by Cambridge University Press on behalf of the German Law Journal. This is an Open Access article, distributed under the terms of the Creative Commons Attribution licence (http://creativecommons.org/licenses/by/4.0/), which permits unrestricted re-use, distribution, and reproduction in any medium, provided the original work is properly cited. 
from an economic "businessmen's Europe" to a "people's Europe"1; the Charter of Fundamental Rights is said to have ushered in a more rights-centered vision of the European project ${ }^{2}$; the Lisbon Treaty is intended to have established a more robust and expansive conception of European citizenship; ${ }^{3}$ and so on.

Among other issues, the place of human rights in the jurisprudence of the CJEU has been the subject of conflicting assertions. ${ }^{4}$ Some commentators have stressed the growing role of the CJEU "as a human rights adjudicator" ${ }^{5}$ that "has evolved from being a tribunal concerned primarily with economic matters to one with a much wider range of jurisdiction which is now explicitly tasked with enforcing human rights." ${ }^{16}$ For many, the coming into force of the Lisbon Treaty marked the EU's new age as a human rights actor, ${ }^{7}$ where the EU's center of gravity is no longer limited to the policy areas such as free trade, the single market and regulation ${ }^{8}$, but has expanded to the fields typically reserved for its sister organization, the Council of Europe. ${ }^{9}$ Others have cast doubt on the ability of the CJEU to act as a human rights actor. ${ }^{10}$ Interestingly, some CJEU judges have explicitly declared that their Court is not a "human rights court." 11 While it has been claimed that the use of human rights discourse by the CJEU reflects less an aspiration to promote rights than a desire to strengthen the principles of supremacy, autonomy, and legitimacy of EU law, ${ }^{12}$ some see the recent case law as evidence that the CJEU is taking rights more seriously. ${ }^{13}$ Yet, given the unrepresentative character of the sample of EU legal materials on which these statements - be they about human rights or about the shift away from economic integration-likely rely, it is not illegitimate to ask whether they actually provide an accurate depiction of reality. Have

\footnotetext{
${ }^{1}$ Jennifer M Welsh, A Peoples' Europe? European Citizenship and European Identity, 13 (European Culture Research Centre, Working Paper No. 25, 1993); Richard C. Eichenberg \& Russell J. Dalton, Post-Maastricht Blues: The Transformation of Citizen Support for European Integration, 1973-2004, 42 ACTA POLITICA 128 (2007).

${ }^{2}$ Gràinne De Búrca, After the EU Charter of Fundamental Rights: The Court of Justice as a human rights adjudicator?, 20 MaAstricht J. Eur. \& CoMP. L. 168-84 (2013); Gráinne de Búrca, The Road not Taken: The European Union as a Global Human Rights Actor, 105 AM. J. INT'L L. 649 (2011); Sionaidh Douglas-Scott, The European Union and Human Rights after the Treaty of Lisbon, 11 Hum. RTs. L. Rev. 645-82 (2011); Jörg Polakiewicz, EU Law and the ECHR: Will EU Accession to the European Convention on Human Rights Square the Circle?, SSRN (2013); Sara Sánchez Inglesias, The Court and the Charter: The impact of the entry into force of the Lisbon Treaty in the ECJ's approach to fundamental rights, 49 COMMON MKT. L. REV. 1565-1612 (2012).

${ }^{3}$ Annette Schrauwen, European Union Citizenship in the Treaty of Lisbon: Any Change at All?, 15 MAASTRICHT J. EUR. \& CoMP. L. 55 (2007).

${ }^{4}$ See De Búrca, supra note 2.

${ }^{5} I d$. at 169 .

${ }^{6} I$ d. at 171. De Burca emphasizes that a significant part of the EU law "corpus now covers areas such as immigration and asylum, security and privacy, alongside many of the more traditional fields of EU policy including competition and market regulation."

${ }^{7} I$. at 649; Sánchez, supra note 2, at 1565.

${ }^{8}$ See Douglas-Scott supra note 2, at 645.

${ }^{9}$ See De Búrca, supra note 2, at 650.

${ }^{10}$ See Douglas-Scott supra note 2, at 645; Tobias Lock, Walking on a Tightrope: The Draft ECHR Accession Agreement and the Autonomy of the EU Legal Order, 48 Common MKT. L. Rev. 1025 (2011); Polakiewicz, supra note 2; De Búrca, supra note 2 , at 172 .

${ }^{11}$ Declaration by CJEU President Vassilios Skouris, FIDE Conference, Copenhagen, May 2014, in Julian Nowag, EU Law, Constitutional Identity, and Human Dignity: A Toxic Mix? Bundesverfassungsgericht: Mr R, 53 CoMMON MKT. L. REv. 1441, 1452 (2016); See Douglas-Scott supra note 2, at 649.

${ }^{12}$ See Douglas-Scott supra note 2, at 649; Jason Coppel \& Aidan Neill, The European Court of Justice; Taking Rights Seriously?, 29 Common MKT. L. Rev. 669, 672 (1992). That the CJEU's use of human rights as a defense for the principle of supremacy, Coppel and O'Neill wrote, can be seen from the fact that the Court placed fundamental rights on the same conceptual level as the principle of economic freedom and the free movement of goods. Id. at 689; see also Case C-222/86, UNECTEF v. Heylens, 1987 E.C.R. 4098, 4117, https://eur-lex.europa.eu/legal-content/HR/TXT/?uri=CELEX\% 3А61986CJ0222.

${ }^{13}$ Coppel \& Neill, supra note 12 , at 669.
} 
the Maastricht and Lisbon treaties really marked inflections in the focus of EU legislators and judges? Is EU law more about markets than it is about rights and citizens? To give but one example, the most popular EU law textbook ${ }^{14}$ devotes seventeen percent of its attention-as measured in pages - to human rights, citizenship, anti-discrimination law, and criminal matters. But is this representative of the prominence of these topics in EU legislation and CJEU rulings? In other words: does legal scholarship provide an accurate picture of the balance of issues that form the bulk of EU legislation and adjudication?

Before joining the CJEU as Advocate General, Michal Bobek criticized legal scholars for their overemphasis on constitutional cases:

The normal life of EU law is not defined by grand constitutional battles on the question of EU law supremacy over national law that reach the courts once in every ten years, but rather by thousands of dull tax cases, consumer protection actions, common customs tariff classification disputes, trans-border enforcement of small civil claims, companies' shareholders quarrels and so on. ${ }^{15}$

Similarly, in a seminal article penned together with Hans-Wolfgang Micklitz, Rob van Gestel, who himself specializes in legislative drafting, has lamented the tendency of EU law scholarship to lapse into "case law journalism." 16 Are these fair characterizations of EU law scholarship? Do EU law academics overly concentrate on constitutional questions, thereby misleadingly suggesting that they represent the daily life of EU law? Do they overly focus on the agenda of its adjudicator in chief?

Because of the aforementioned cognitive challenge, such questions may appear impossible to answer with much certainty. But imagine that we could find a way to systematically summarize the contents of all EU legislative acts and all CJEU judgments issued over the EU's lifetime. Imagine, too, that we were able to do the same for a large, plausibly representative, sample of academic contributions. Equipped with these summaries, we would be in a position to evaluate the veracity of these claims.

This is, in a nutshell, what the present Article purports to do. We explore a mega EU law corpus - comprising the entire universe of legislative acts adopted since 1966-,all CJEU judgments and opinions published since 1963, and all articles from the Common Market Law Review (CMLR)

\footnotetext{
${ }^{14}$ Paul Craig \& Grainne de Búrca, EU law: Text, Cases, and Materials (Oxford Univ. Press 2015).

${ }^{15}$ Michal Bobek, Of Feasibility and Silent Elephants: The Legitimacy of the Court of Justice Through the Eyes of National Courts, R.R.D.E. 57 (2014) in Maurice Adams, Et Al., Judging Europe's Judges: The Legitimacy of Case LaW of the European Court of Justice Examined 200 (Hart Pub. 2013). In a similar vein, Hans Micklitz has argued that contrary to Karen Alter's claim, it is not court competition or the desire to get empowered vis-à-vis higher courts that drives courts' participation in Article 267 TFEU proceedings, but the desire to resolve technical disputes at the national level. See Hans-W Micklitz, The Politics of Judicial Co-Operation in the EU: Sunday Trading, Equal Treatment and Good Faith 433 (Cambridge Univ. Press 2005). See also Urszula Jaremba, National Judges as EU Law Judges: The Polish Civil Law System, 341 (2014). Alter's court competition thesis was originally articulated in Karen J Alter, Explaining National Court Acceptance of European Court Jurisprudence: A Critical Evaluation of Theories of Legal Integration in Anne Marie Slaughter, Alec Stone Sweet \& Joseph Weiler, The European Court and National Courts: Doctrine and Jurisprudence: Legal Change In Its Social Context, (1998).

${ }^{16}$ Rob van Gestel \& Hans-Wolfgang Micklitz, Why Methods Matter in European Legal Scholarship, 20 EUR. L. J. 292 , 298 (2014). The expression "case law journalism" was coined by Pierre Schlag, in Spam Jurisprudence, Air Law, and the Rank Anxiety of Nothing Happening (A Report on the State of the Art), 97 GEO. L. J. 821 (2009). In his sharp critique of legal scholarship, Schlag writes that "the case-law journalist inserts the cases into some sort of normative narrative. Almost invariably, the case-law journalist ends on a cheery normative prescription for betterment of law, nation, or world." Id. at 823 .
} 
published since 1963 and up to 2018. We then map issue proportion in this mega corpus by applying a natural language processing technique known as probabilistic topic modelling, which leverages the power of unsupervised machine learning to annotate and classify texts with little human input. We use this technique to construct visual representations and metrics of issue emphasis across time and sources.

Aside from mapping issue prevalence across our legislative, judicial, and academic sub-corpora, our computer-aided text analysis documents several trends. First, economic and market integration has been, and continues to be central to, EU legislation and CJEU rulings. EU law is, in that sense, still predominantly about homo economicus rather than homo politicus or homo juridicus. Second, social policy issues - social benefits, pension rights, housing, etc.-feature more prominently in CJEU cases than in legislation. Third, whereas farming regulation and the Common Agricultural Policy (CAP) account for a large share of legislative and judicial activity, they hardly receive any attention from legal scholars-at least those who contribute to CMLR. ${ }^{17}$ Fourth, although attention to human rights has increased across the three categories of documents, human rights topics are significantly more prominent in the writings of academics than in the textual production of legislators and judges.

These findings, we speculate, can be rationalized, in significant part, by the distinct institutional incentives and constraints that determine the thematic orientation of the text producers. EU law text producers operate in separate, but nonetheless interrelated, institutional environments. Institutional conditions allow for differing patterns of emphasis. Yet EU law text producers cannot sing entirely divergent tunes. To characterize the nature of the relationship among these partly interdependent, partly autonomous voices of EU law, we suggest a biological analogy and propose to conceptualize the interplay of text producers as a form of co-evolution. The concept of co-evolution underscores the degree of interdependence among the three voices of EU law. Yet it does not imply that independence must necessarily be symmetric or reciprocal. Our textual analysis suggests that legislation influences issue attention on the CJEU, which, in turn, affects what law professors choose to write about. However, the causal arrow rarely seems to travel in the opposite direction while patterns of emphasis in legislation and law review articles appear to diverge considerably.

Importantly, our methodological approach does not impose any a priori classification on our corpus. Instead, our modus operandi allows topics to emerge from the analysis. This point bears emphasis because our starting point is precisely that nobody can realistically claim to know the entire set of legal issues and policy areas addressed by legislation, court cases, and law review articles. Any attempt to devise a classification scheme a priori-that is, before one gets a comprehensive overview of the actual continents of the textual data-is bound to result in categories biased towards the domains known to the analyst.

The remainder of the article is structured as follows. First, we reflect on the text generating process - the factors that have the potential to shape our legal authors' choice of subject. On the face of things, it would seem that one could not imagine more different legal writers than

\footnotetext{
${ }^{17}$ The work of Francis Snyder, however, deserves mention. See, e.g., Francis G. SNyder, Law OF THE COMmON Agricultural Policy, Sweet \& Maxwell (1985); Francis G Snyder, The Special legal Status of Agriculture: Assumptions and Contradictions in Economic Law, New Directions in European Community LaW (1990); Francis Snyder, The Common Agricultural Policy in the Single European Market, Academy of European Law, Collected Courses of the Academy of European law, vol 2 (1992); Francis Snyder, The Use of Legal Acts in EC Agricultural Policy, Sources and Categories of European Union Law: A Comparative and Reform Perspective (1996); Francis Snyder, 'CAP' The Oxford Handbook of the European Union (2012); Francis Snyder \& Ahmed Mahiou, La SÉcurité Alimentaire/Food Security and Food Safety (Centre for Studies and Research in International Law ed., 2006). See also Alison Burrel, The CAP: Looking Back, Looking Ahead, 31 EUR. INTEGRATION 271 (2009).
} 
legislators, judges, and law professors. Yet we argue that, although these legal authors are subject to differing institutional incentives and constraints, litigation often brings the output of EU legislators before the CJEU. Legal academics, meanwhile, are expected to cover judicial developments at least as much as legislative ones. We introduce the concept of co-evolution to make sense of the dependencies among our three categories of EU law text producers. Second, we present our corpus and text-mining methodology. While describing our rich corpus, we explain the basic assumptions underpinning probabilistic topic modelling. We emphasize the unsupervised, let the data speak character of the technique and its analytical leverage for the exploration of large collections of legal texts. Third, and finally, we report and discuss our results. We do so mainly through visuals comparing topic prevalence across legislation, court cases, and law review articles synchronically and over time. We conclude with some thoughts and suggestions on how to further refine our findings and how computer-aided text-mining methods ameliorate our understanding of the law.

\section{B. The Production and Co-evolution of EU Law Texts}

EU legislators, CJEU judges, and academics who write about EU law operate in very different institutional environments. Depending on the policy domain and legislative procedure, the adoption of EU legislation may involve Commissioners, national government representatives, MEPs, and various committees. ${ }^{18}$ Procedures have changed over time, as new treaties extended qualified majority voting and created new legal bases for EU rulemaking while vesting new powers in the European Parliament.

Formally speaking, the European Commission has a general monopoly over legislative initiatives. Politically though, national governments play a key role in defining the broad contours of the legislative agenda announced in European Council meetings. ${ }^{19}$ Together, the Commission and the European Council effectively act as the main legislative agenda-setters. Yet, thanks to the extension of its co-decision powers, the European Parliament has become a powerful veto-player able to block the passage of legislative proposals supported by the other institutions. ${ }^{20}$ At the high level of generality assumed in this Article, MEPs, Commissioners, and national governments can be viewed as the main authors of EU legislation-although their respective influence over the legislative has fluctuated as a result of shifts in the prevailing balance of powers under the successive treaty regimes.

Unlike EU legislators such as the European Commission, CJEU judges cannot act sua sponte. They can only engage with an issue if a litigant files a suit. Case initiators act, in that sense, as functional co-authors of the judges' written output.

To the extent that litigation dynamics effectively determine the actual scope of judicial discourse, examining who enjoys the right to initiate a case and under what conditions should go

\footnotetext{
${ }^{18}$ Simon Hix \& Bjorn Hoyland, The Political System of the European Union, Palgrave Macmillan, (2011); Thomas Christiansen \& Mathias Dobbels, Non-Legislative Rule-Making after the Lisbon Treaty: Implementing the New System of Comitology and Delegated Acts, 19 Eur. L. J. 42 (2013).

${ }^{19}$ Sebastiaan Princen, Agenda-Setting in the European Union, Springer (2009); Amie Kreppel \& Buket Oztas, Leading the Band or Just Playing the Tune? Reassessing the Agenda-Setting Powers of the European Commission, 50 Comp. POL. STUd. 1118 (2017); Sebastiaan Princen, Agenda-Setting in the European Union: A Theoretical Exploration and Agenda for Research, 14 J. EuR Pub. POL. 21 (2007).

${ }^{20}$ For an elaboration of the European Parliament's ability to influence agenda setting under various decision rules see George Tsebelis, The Power of the European Parliament as a Conditional Agenda Setter, 88 Am. Pol. SCIEnCE Rev. 128 (1994); George Tsebelis, More on the European Parliament as a Conditional Agenda Setter: Response to the Moser, 90 AM. Pol. SCI. REv. 839 (1996); George Tsebelis \& Geoffrey Garrett, The Institutional Foundations of Intergovernmentalism and Supranationalism in the European Union, 55 INT'L ORG. 357 (2001).
} 
some distance towards explaining what questions occupy the judges' agendas. Differences in procedural setup translate into different dockets, with judicial issue attention varying according to the priorities of the enfranchised case initiators.

The three main procedures governing access to the Court of Justice and the General Court come with distinct causes of action, remedies, and standing rules. Infringement cases may be brought by national governments, who rarely do so, or the European Commission-who is meant to serve as chief European prosecutor. The right to bring annulment actions against EU acts is vested in EU institutions and member state governments. Only in restricted circumstances do private litigants wield the same right. Preliminary references are ordinarily viewed as providing a more open access channel to non-institutional litigants, ${ }^{21}$ although the decision to refer ultimately lies with the domestic court hearing the case.

Compared to judges and legislators, legal academics would seem to enjoy greater leeway in deciding what to write about. After all, the liberty to choose what one writes about arguably constitutes a cornerstone of academic freedom. However, several factors conspire to make academic writing more predictable than this principle, alone, would suggest. First, bar association regulations and law school curricula often determine what law has to be taught. Together with habit and tradition, these institutional factors influence which candidates are looked for and hired on the academic job market. We speculate that the topic on which legal academics choose to specialize is often influenced by the courses and instructors that they were exposed to during their studies and the specialization of their doctoral supervisor, thereby inducing a great deal of thematic continuity in the focus - and methodology — of legal scholarship. Second, despite attempts to revive the study of legislation, ${ }^{22}$ legal education and legal scholarship tend to concentrate on judicial activity to such an extent that studying law is often implicitly equated with studying court rulings. Van Gestel and Micklitz's "case law journalism" quip suggests that EU law scholarship is equally obsessed with court rulings. ${ }^{23}$ Third, from the perspective of legal academia, judicial decisions themselves are not all born equal. Decisions that only resolve individual disputes without altering the stock of legal doctrines are of little interest to legal scholars, who typically restrict their doctrinal inquiry to the decisions that have the potential to become precedents. Finally, one should not underestimate the power of fashion in shaping the interests of academic writers. Some topics - say judicial independence in Central and Eastern European member states-simply appear more exciting than others, for example, VAT.

While operating within distinct institutional frameworks, the three sites of EU law text production are nonetheless interrelated. CJEU judges are asked by litigants to review the validity of EU acts or to clarify their meaning. Adjudication, in that sense, responds to legislation, although always through the mediation of litigation. There might also be instances where EU legislators respond to CJEU rulings, although the evidence suggests that these cases are rare. ${ }^{24}$ Legal scholarship has a greater degree of autonomy both vis-à-vis judges and vis-à-vis legislators. Yet what prompts an EU law scholar to write an article is often a salient CJEU ruling. Furthermore, a study by Harm Schepel and Rein Wesseling found a significant proportion of articles in the Common

\footnotetext{
${ }^{21}$ Karen J Alter, Private Litigants and the New International Courts, 39 ComP. POL. STUD. 22 (2006).

${ }^{22}$ Ittai Bar-Siman-Tov, The Global Revival of Legisprudence: A Comparative View on Legislation in Legal Education ANd Research, Conceptions and Misconceptions of Legislation (2019).

${ }^{23}$ See van Gestel \& Micklitz, supra note 16, at 298.

${ }^{24}$ See the discussion on legislative overrides in Olof LARsSon, Political AND CONSTITUTIONAL OverRides: The CASE OF the Court of Justice of European Union, Journal of European Public Policy (2020); Olof Larsson \& Daniel Naurin, Judicial Independence and Political Uncertainty: How the Risk of Override Affects the Court of Justice of the EU, 70 INT'L ORG. 377-408 (2016); Gareth Davies, Legislative control of the European Court of Justice, 51 COMMON MKT. L. REV. 1579-1607 (2014).
} 
Market Law Review, the Cahiers de droit européen, and Europarecht to have authors affiliated with the European Commission, the CJEU or other EU institutions. ${ }^{25}$ We would expect such institutional links to increase thematic overlap across legislative, judicial, and academic discourse.

A helpful concept to capture the dynamic relationship between these three sources of EU law writings is that of co-evolution. Borrowed from biology, the term co-evolution designates a process by which two or more distinct groups evolve in tandem through reciprocal influence. ${ }^{26}$ Applied to EU law discourse, this definition suggests that legislative, judicial and academic writers constitute separate but interdependent groups. Even though the concept of convolution does not necessarily entail that reciprocal influences are symmetric in magnitude, it implies that one group cannot exist, or at least not in the same way, without the other. It is, indeed, difficult to imagine how EU scholarship would look like were the CJEU to stop issuing decisions. Assuredly, EU law scholarship would then lose its principal raison d'être. In like fashion, much of the decision-making activity of CJEU judges would simply evaporate if the Commission, Parliament, and Council ceased to produce legislation. Yet, because of legal scholars' focus on courts and relative neglect of legislation, we should expect considerable thematic overlap between judges and legislators, and judges and academics, but less between academics and legislators.

\section{EU Law as Data}

\section{EU Law Corpus}

We used computer scripts written in the programming language $R$ to extract legislative acts and CJEU documents from the EUR-Lex website. CMLR articles were obtained from the journal's webpage repository to which we had access through our host institution. While there are other well established legal periodicals specializing in EU law, CMLR is the longest running among the Anglophone journals-its launch predating its main competitors by more than two decades. Whereas its editorial policy does, to some extent, differ from that of the European Law Journal and the European Law Review - it does not publish much interdisciplinary legal research and, initially at least, had a marked focus on market integration-it seems reasonable to assume that articles and case notes appearing in CMLR constitute a fairly representative sample of Anglophone EU law scholarship and of its evolution over time. ${ }^{27}$

As some documents-notably older legislative texts and CJEU decisions-were only available in PDF format, we applied optical character recognition to digitalize them. Although we collected the entire universe of published legislative and CJEU documents from 1953 onwards, our operational corpus - the one we use to perform our text-mining analyses-ignores legislative documents issued prior to 1966 and CJEU documents produced prior to 1963 . The reason is that the very low number of legislative acts and judicial documents issued prior to these dates proved a source of modelling complications. Yet these documents constitute a tiny fraction of the corpus, meaning that this methodological choice can be regarded as innocuous.

The three sets of documents, or sub-corpora, making up our operational corpus are summarized in Table 1. The first and smallest sub-corpus consists of 3809 CMLR articles and case notes.

\footnotetext{
${ }^{25}$ Harm Schepel \& Rein Wesseling, The Legal Community: Judges, Lawyers, Officials and Clerks in the Writing of Europe, 3 EuR. L. J. 165 (1997); Koenraad Lenaerts, La vie après l'avis: Exploring the Principle of Mutual (Yet not Blind) Trust, 54 COMMON MKT. L. ReV. 805-40 (2017).

${ }^{26}$ On the notion of coevolution in the social and natural sciences see Miguel A Gual \& Richard B Norgaard, Bridging Ecological and Social Systems Coevolution: A Review and Proposal, 69 ECOLOGICAL ECON. 707 (2010); the term 'coevolution' was originally coined by Paul R Ehrlich \& Peter H Raven, Butterflies and Plants: A Study in Coevolution, 18 EvoluTiON 586 (1964).

${ }^{27}$ Our assumptions here are congruent with those of the aforementioned study by Harm Schepel and Rein Wesseling that also chose CMLR as representative of Anglophone EU law scholarship, see Schepel \& Wesseling, supra note 25, at 171.
} 
Table 1. Description of sub-corpora

\begin{tabular}{|c|c|c|c|c|c|}
\hline $\begin{array}{l}\text { Sub-cor- } \\
\text { pus }\end{array}$ & $\begin{array}{l}\text { Number of docu- } \\
\text { ments }\end{array}$ & $\begin{array}{l}\text { Average number of } \\
\text { words }\end{array}$ & $\begin{array}{l}\text { Standard } \\
\text { deviation }\end{array}$ & $\begin{array}{l}\text { Min number of } \\
\text { words }\end{array}$ & $\begin{array}{c}\text { Max number of } \\
\text { words }\end{array}$ \\
\hline CMLR & 3,809 & 6,991 & 6,175 & 28 & 84,741 \\
\hline CJEU & 55,703 & 2,760 & 4,525 & 15 & 151,786 \\
\hline Legislation & 194,655 & 1,748 & 7,085 & 6 & 694,435 \\
\hline
\end{tabular}

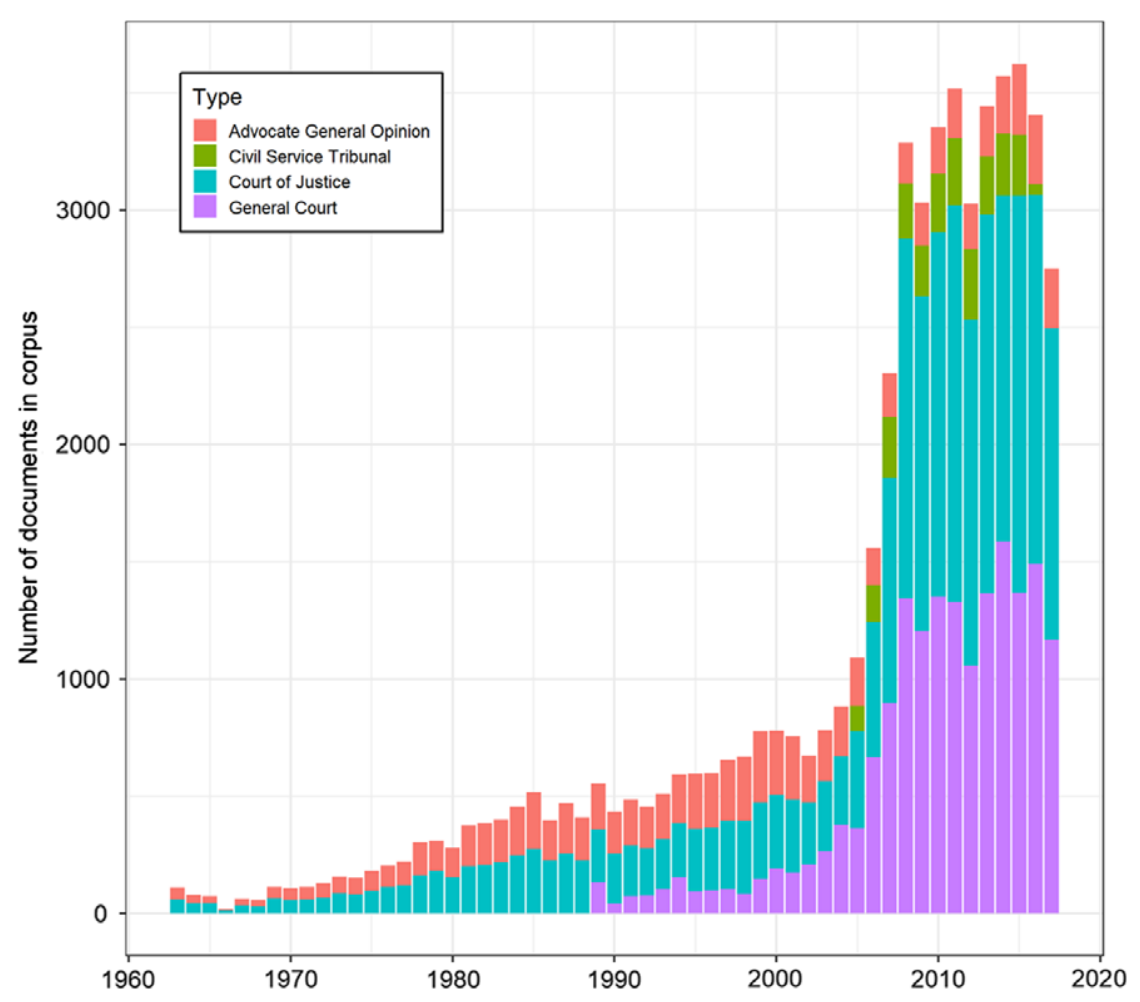

Figure 1. Documents in judicial sub-corpus by year of issuance.

The second set of documents encompasses all Court of Justice, General Court, and Civil Service Tribunal opinions and judgments along with all Advocate General opinions issued since 1963 and available at the time of writing. Figure 1 illustrates the distribution of these judicial documents over time. Whereas the number of Advocate General opinions has remained more or less constant since the 1970s, the number of Court of Justice and General Court rulings has experienced a sharp increase from 2005 onwards. The third and, by far the largest, sub-corpus comprises all the legislative acts passed by the European Union institutions between 1966 and 2017. Legislative acts include treaties, directives, regulations, and decisions. Figure 2 shows the proportion of directives, regulations, and decisions over time. Regulations clearly account for the bulk of legislative activity. Striking, too, is the decline in legislative production since the turn of the millennium. 


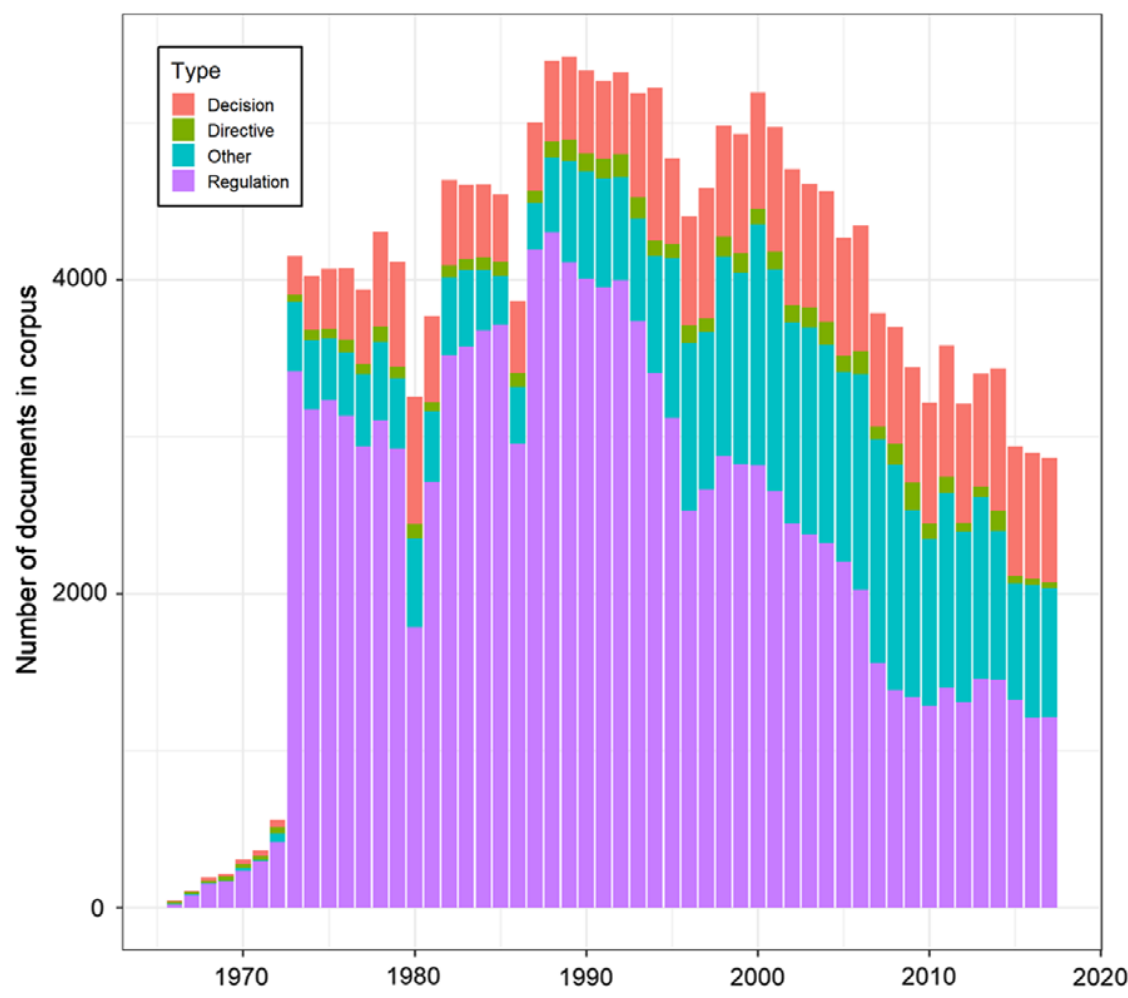

Figure 2. Document types in legislative corpus by year of issuance.

Naturally, for the reasons discussed in the previous Section, there are limits to what we should expect to find in the substantive content of EU legislation, case law, and academic publications in our corpus. Obviously, the diversity of topics reflected in EU legislation is constrained by the breadth of the EU's legislative powers. Although the EU has been regularly accused of intruding on national sovereignty, for example through an expansive interpretation of its internal market competences, the EU is, in general, more likely to enact legislation on issues close to its historical core competences - agriculture, international trade - than in areas lacking an explicit legal basis in the treaties, such as human rights or the rule of law. Similarly, the content of CJEU case law might be more likely to reflect justiciable issues, although, when it comes to preliminary rulings, national courts are free to refer questions concerning any EU rules deemed relevant to the dispute at hand. As for the CMLR, the decisions and policies of the journal's editors undeniably play a significant role in filtering what gets published.

Nevertheless, these constraints do not fully determine the contents of the texts eventually produced. At any rate, they leave ample room for variations resulting from factors either endogenous - such co-evolutionary influences — or exogenous — such as the preferences of litigants and academics - to the text-generating process.

\section{Methodology}

Our main text-mining method is known as probabilistic topic modelling. ${ }^{28}$ Probabilistic topic modelling has been developed for the purpose of discovering and annotating large archives of

\footnotetext{
${ }^{28}$ David M Blei, Probabilistic Topic Models, 55 ComM. ACM 77 (2012).
} 
documents with thematic information. As with all-natural language processing techniques, probabilistic topic modelling relies on simplifying assumptions-in short, it does not parse words, sentences and contexts quite the way the human brain does. Yet, it has been shown to perform well on a wide range of documents, including legal ones. ${ }^{29}$ Probabilistic topic modelling is an unsupervised machine learning method. That is to say, the document classification is not learned from human annotations, but "discovered" by the algorithm itself. The basic intuition behind the technique is that documents addressing the same topic are likely to contain similar words. Words such as "import", "products" and "tariffs" will appear more often in documents about trade whereas "residence," "citizenship," "family" and "visa" will be more common in documents about immigration. Also, a document, whether a legislative act, a ruling or a law review article, will frequently straddle several topics. A ruling about a procedural or constitutional issue will also refer to the more substantive issue of the case-which may be milk quotas or wildlife conservation.

Topic modelling builds on these assumptions to model topics as clusters of words and documents as mixtures of topics. In more technical language, a topic model posits a latent space in which topics are represented as probabilistic distributions over words and documents as probabilistic distributions over topics. Once the researcher has set the desired number of topics, commonly denoted by the letter $k$, the algorithm seeks the topics-conceptualized as clusters of words - that best classifies the documents-modelled as mixtures of topics-in the corpus.

The $k$ number of topics chosen to represent the content of a corpus is set by the researcher. This parameter is best viewed as determining how fine-grained a picture of the corpus the final topic model should provide. ${ }^{30}$ A large $k$ will result in a model with lots of very specific topics. A smaller $k$ will produce a model with fewer topics but broader themes. For our analysis of EU law, we construct four topic models. One for the aggregate corpus and one for each of the three sub-corpora. For each of these models, we chose a number of topics that appeared to strike a reasonable balance between precision and tractability. As opposed to the number of topics, the words defining the topics are not chosen by the researcher, but are produced by the model. For that reason, probabilistic topic modelling is known in natural language processing as an unsupervised document classification technique.

Given the considerable temporal variation in document numbers, as illustrated in Figures 1 and 2 , one might be concerned that a computerized text analysis would be skewed towards the period in which the largest number of documents has been produced. For the CJEU, for instance, we might fear that our topic model would essentially be a representation of topic prevalence after 2005. This is why the topic model we utilize is dynamic. It assumes that thematic attention may change over time and, for that reason, gives each year the same weight in the computation.

Before feeding them to the algorithm, documents were pre-processed, as is standard practice in natural language processing tasks. Pre-processing steps involved removing words and symbols that provide no thematic information: Punctuation, numbers and very frequent terms such as

\footnotetext{
${ }^{29}$ Blei, supra note 28; Michael A Livermore, Allen B. Riddell \& Daniel Rockmore, Agenda Formation and the US Supreme Court: A Topic Model Approach, ArIz. L. Rev. (2016); David J Carter, James Brown \& Adel Rahmani, Reading the High Court at a Distance: Topic Modelling the Legal Subject Matter and Judicial Activity of the High Court of Australia, 1903-2015, 39 UNSW L. J. 1300 (2016).

${ }^{30}$ Heuristics, such as perplexity and semantic exclusivity, have been proposed for choosing $k$ values, see the discussion in Jonathan Chang Et. Al., Reading Tea Leaves: How Humans Interpret Topic Models, Advances in neural information processing systems (2009); Hanna M Wallach, Et. Al., Evaluation Methods for Topic Models', Proceedings of the 26TH annual international Conference on machine learning, ACM (2009); David Mimno, Hanna Wallach, Edmund Talley, Miriam leenders \& Andrew McCallum, Optimizing Semantic Coherence in

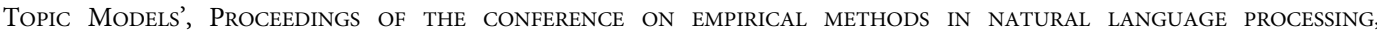
AssOCIATION FOR COMPUTATIONAL LINGUISTICS (2011). However, these heuristics do not only lack validity. Even if they were valid, there is no "correct" $k$ independently of the context and aim of the research.
} 
"the," "but," and "with." We also removed words that appear in a high proportion of documents, as they are not useful for discriminating between different topics and make the interpretation of the model more difficult. Characters were all converted to lowercase so as to ensure that "Legal" and "legal," for example, are treated as the same word. ${ }^{31}$ All these steps were performed using the $R$ programming language.

\section{Variations in Issue Attention in Legislative, Judicial and Academic Texts}

This Section presents and discusses the results of our topic modelling exercise.

\section{Mega Topic Model of EU Law}

We begin our textual exploration of EU law with our "mega" topic model, which treats the three text collections as a single corpus. The model summarizes this aggregate corpus in 63 topics. For this topic model, we restricted the analysis from 1972 through 2017 to facilitate interpretation. ${ }^{32}$

Plotted in Figure 3 are the 63 topics with their four most characteristic words. It is important to bear in mind that these words have not been selected by the researchers, but are produced by the algorithm. We did not know in advance what topics would emerge from the model.

Interpreting the keyword-like terms defining a topic requires some basic knowledge of EU law and institutions. For example, the terms "questions," "interpreted," "referring," "jurisdiction" may not seem readily meaningful to a layperson, but a jurist with some knowledge of EU law will instantly recognize words associated with the preliminary ruling procedure.

In Figure 3, the position a topic occupies on the horizontal axis indicates its overall prevalence in the corpus. The most prevalent topic appears in the upper-right region of the plot. Its most characteristic terms are "wheat," "flour," "malt" and "rye." This topic accounts for more than 6 percent of the overall thematic attention. The second most prevalent topic is defined by the terms "sugar," "raw," "white" and "sucrose." The fourth — 'fruit, vegetables, values, agriculture' and fifth - "rice, grain, broken, starch" - most-prevalent topics are also related to agriculture. The topic in the third position from the top- "tender, invitation, tenders, intervention" — suggests that public procurement is another area of intense activity.

While we do find topics pertaining to judicial and constitutional issues-for example, "constitutional, courts, fundamental, political"-the overwhelming majority of topics address either trade, market or farming activities. As we shall see when we examine the separate topic models for legislation, CJEU documents and CMLR contributions, the predominance of economic and farming issues is in large part the consequence of the legislators' voice. Yet these themes also feature prominently, albeit to a lesser extent, in the CJEU's dispute settlement activity.

\section{Legislative, Judicial, and Academic Sub-corpora}

For the three sub-corpora, we chose topic models with, respectively, 35 -legislation and courtand 45 CMLR topics.

We first examine the model corresponding to the largest sub-corpus, EU legislation. We find, again, a high proportion of agriculture-related topics, with again cereals- "wheat, flour, maize, malt"—sugar-"sugar, white, basic, exported"—and rice_-rice, grain, broken, processed"—

\footnotetext{
${ }^{31}$ The final pre-processing step involved transforming the pre-processed corpus in a document-term matrix, in which each document is represented as a row and each term as a column. The matrix cell corresponding to a given document and a given term indicates how many times this particular word occurs in that particular document.

${ }^{32} \mathrm{~A}$ topic model including documents issued over the period 1966-1971 produced topics more difficult to interpret. This problem results from the lower number of documents produced in this period. It could be addressed by a topic model with significantly a larger $k$ parameter value but this would come in the way of tractability, a topic model with 200 topics or more would take a full article to report.
} 


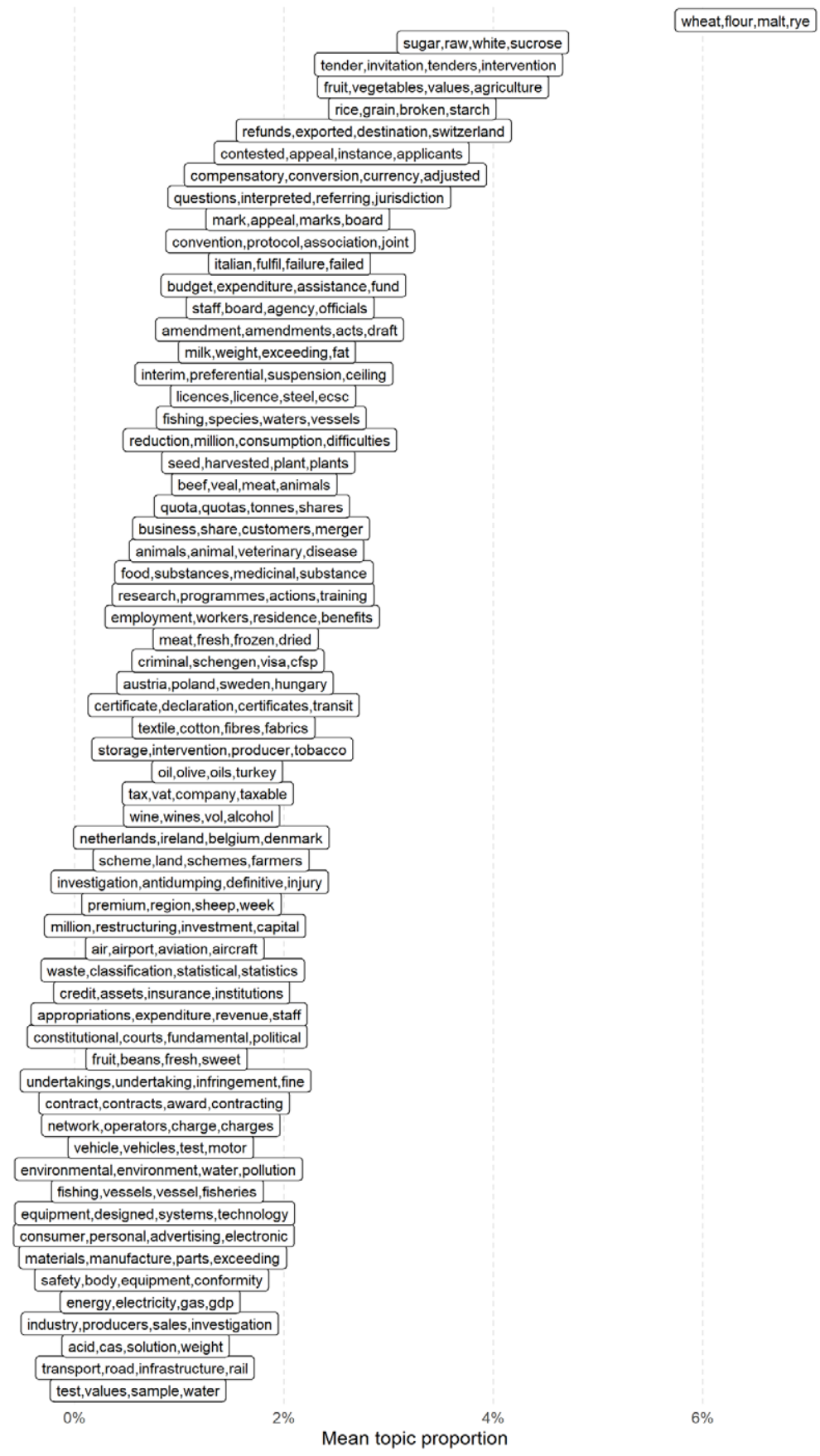

Figure 3. Mega topic model of EU law (1972-2017).

coming out on top. Public procurement comes in the fourth position, but is followed by yet another farming topic — "fruit, values, vegetables, nomenclature." When not with agricultural commodities, other topics deal with competition-for example, topic "competition, business, services, share"-trade-for example, topic "industry, dumping, producers, investigation"-and transportation— “transport, services, service, airport." Only two topics do not seem to bear a direct 


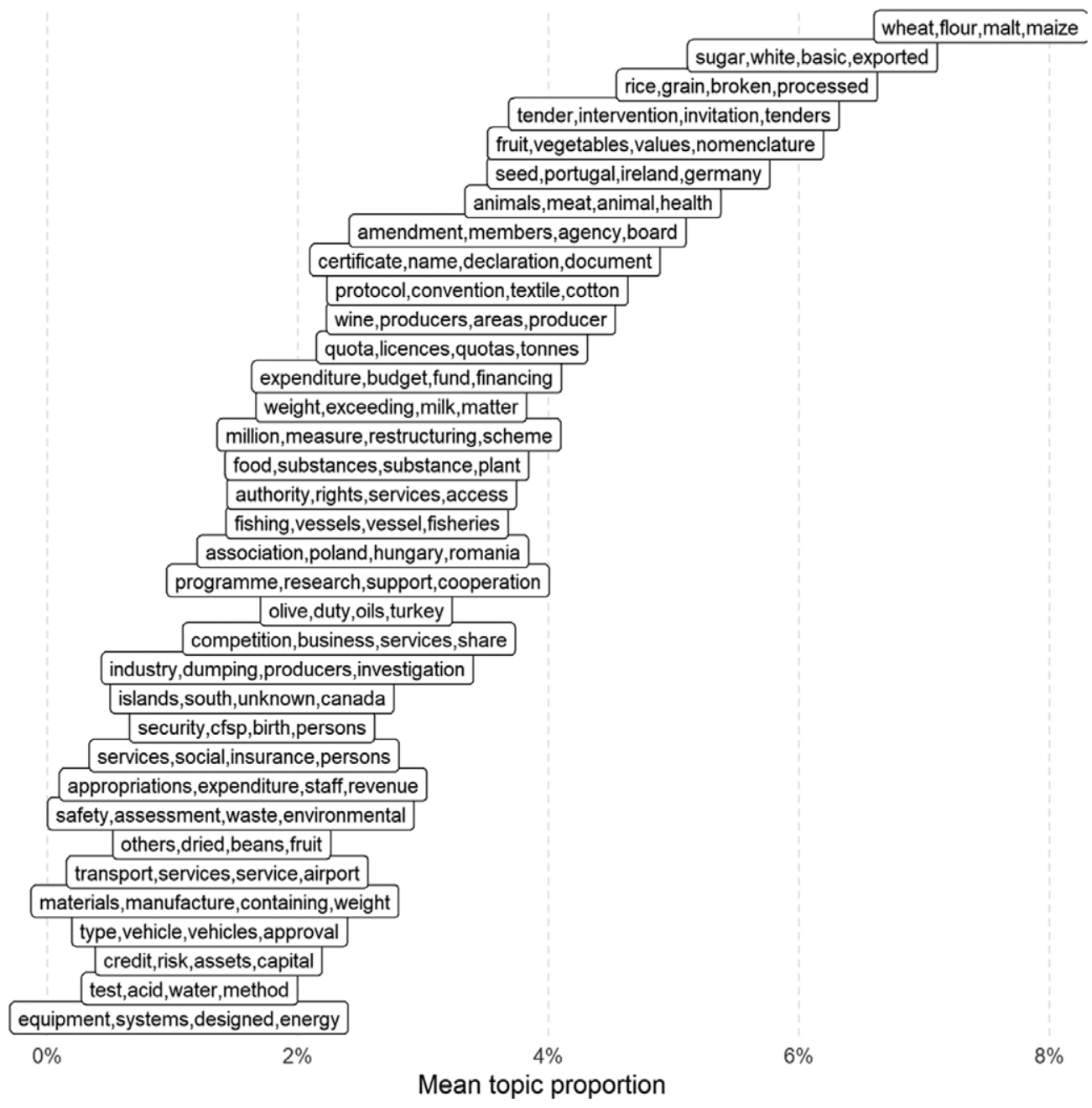

Figure 4. Topics and topic proportion, legislative sub-corpus (1966-2017).

relationship to the single market or the CAP. One relates to the Common Foreign and Security Policy- "security, cfsp, birth, person". The other to environmental protection- "safety, assessment, waste, environmental."

Overall, Figure 4 shows considerable overlap with Figure 3, which is hardly surprising given the imbalance in the size of the three sub-corpora and the hefty share accounted for by legislative documents. If anything, the topics in Figure 4 appear even more technical and market-centered. The high prevalence of farming topics can be explained by the regulatory regime embraced by the CAP, which leans heavily on market intervention. Despite recent reforms, the CAP is not exactly known for its light-touch approach to regulation. ${ }^{33}$ Frequent interventions concerning specific commodities translate into abundant, short-term regulations.

Table 2 shows the legislative documents with the highest topic proportion for a sample of legislative topics. For example, the document with highest proportion of topic "type, vehicle, vehicles, approval" is Directive 2009/67/EC of the European Parliament and of the Council of 13 July 2009

\footnotetext{
${ }^{33}$ Alan Greer, Post-Exceptional Politics in Agriculture: An Examination of the 2013 CAP Reform, 24 J. EUR. PUB. POL. 1585 (2017).
} 
Table 2. Acts with the largest topic proportion for a sample of legislative topics

\begin{tabular}{|c|c|c|c|}
\hline Topic & Act & Year & $\begin{array}{l}\text { Topic pro- } \\
\text { portion }\end{array}$ \\
\hline $\begin{array}{l}\text { type, vehicle, vehicles, } \\
\text { approval }\end{array}$ & $\begin{array}{l}\text { Directive } 2009 / 67 / E C \text { of the European Parliament and of the Council } \\
\text { of } 13 \text { July } 2009 \text { on the installation of lighting and light-signalling devi- } \\
\text { ces on two or three-wheel motor vehicles }\end{array}$ & 2009 & $99.96 \%$ \\
\hline $\begin{array}{l}\text { security, cfsp, birth, } \\
\text { persons }\end{array}$ & $\begin{array}{l}\text { Council Implementing Decision 2012/167/CFSP of } 23 \text { March } 2012 \\
\text { implementing Decision 2011/486/CFSP concerning restrictive measures } \\
\text { directed against certain individuals, groups, undertakings and entities } \\
\text { in view of the situation in Afghanistan }\end{array}$ & 2012 & $99.95 \%$ \\
\hline $\begin{array}{l}\text { fishing, vessels, vessel, } \\
\text { fisheries }\end{array}$ & $\begin{array}{l}\text { Commission Implementing Regulation (EU) } 2017 / 1594 \text { of } 25 \\
\text { September } 2017 \text { adding to the } 2017 \text { fishing quotas certain quantities } \\
\text { withheld in the year } 2016 \text { pursuant to Article } 4(2) \text { of Council } \\
\text { Regulation (EC) No } 847 / 96\end{array}$ & 2017 & $99.89 \%$ \\
\hline $\begin{array}{l}\text { appropriations, } \\
\text { expenditure, staff, reve- } \\
\text { nue }\end{array}$ & $\begin{array}{l}\text { Statement of revenue and expenditure of the Translation Centre for } \\
\text { the Bodies of the European Union for the financial year } 2007\end{array}$ & 2007 & $99.81 \%$ \\
\hline $\begin{array}{l}\text { weight, exceeding, milk, } \\
\text { matter }\end{array}$ & $\begin{array}{l}\text { Commission Regulation (EEC) No } 3567 / 83 \text { of } 16 \text { December } 1983 \text { fixing } \\
\text { the export refunds on milk and milk products }\end{array}$ & 1983 & $99.80 \%$ \\
\hline $\begin{array}{l}\text { rice, grain, broken, } \\
\text { processed }\end{array}$ & $\begin{array}{l}\text { Commission Regulation (EEC) No } 417 / 80 \text { of } 21 \text { February } 1980 \text { fixing } \\
\text { the export refunds on rice and broken rice }\end{array}$ & 1980 & $98.83 \%$ \\
\hline
\end{tabular}

on the installation of lighting and light-signaling devices on two or three-wheel motor vehicles. Table 2 shows how topic modelling can be used to search for legal documents pertaining to a specific topic. A topic model gives us an indication of topic proportion not just for a single document but for all documents in the corpus - which is a great advantage over methods based on keyword search. Inspecting documents with high topic proportion can also help interpret topics that may at first appear ambiguous. For example, the topic "appropriations, expenditure, staff, revenue" may not look immediately obvious, but it becomes very clear when we look at the act featuring the largest proportion of the topic, namely the Statement of the revenue and expenditure of the Translation Centre for the Bodies of the European Union for the financial year 2007.

Moving from legislative to judicial discourse, Figure 5 illustrates our topic model for the CJEU texts. In comparison to legislators, EU judges devote less attention to CAP issues, although these are still well represented - for example, topic "sugar, price, wine, tobacco" and topic "milk, agricultural, quota, levy." The sizable number and monolithic character of staff cases, which for a time were handled by a specialized Civil Service Tribunal, make this topic- "staff, officials, post, committee" - the most prevalent in the judicial corpus. Probably because they rarely, if ever, result in landmark rulings with far-reaching doctrinal and policy implications, staff cases seldom get mentioned in academic publications. Yet, they form a constant source of workload for the EU judiciary. ${ }^{34}$

Beyond staff cases, many topics deal with single market themes-for example, customs, tariff nomenclature, VAT, product packaging, taxation of cross-border operations, competition. Yet, we also see some social policy_ “employment, workers, pension, benefits" — and citizenship themes — "residence, family, nationals, child".

Overall, our unsupervised document classification reveals the judicial sub-corpus to be more diverse than its legislative counterpart. The homo economicus looms large in CJEU adjudication,

\footnotetext{
${ }^{34}$ The Civil Service Tribunal was created in 2005 and abolished in 2016 with its agenda reabsorbed by the General Court.
} 


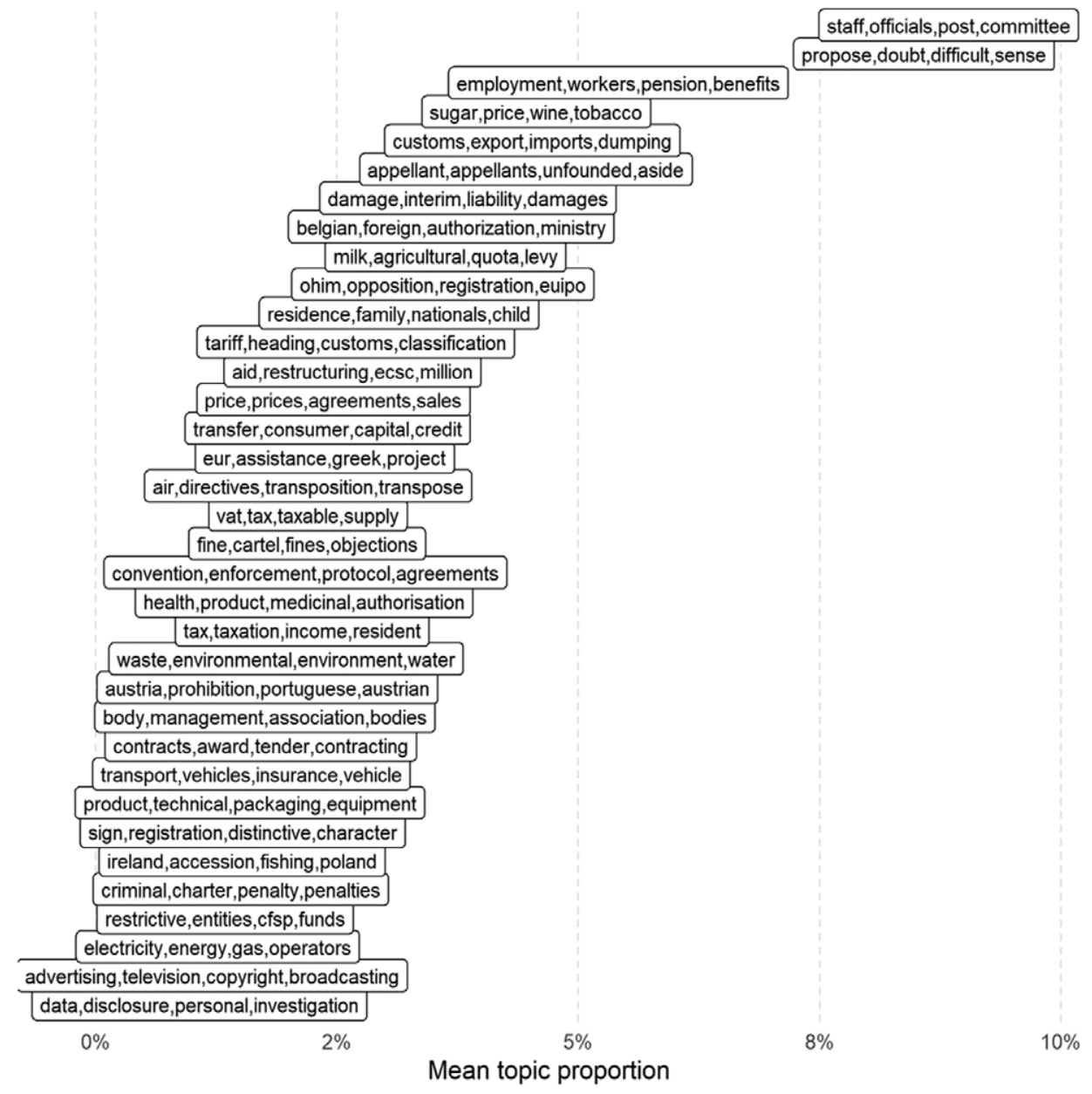

Figure 5. Topics and topic proportion in judicial sub-corpus (1963-2018).

but not as conspicuously so as in legislation. The topic model gives a sense of what the typical case on the CJEU docket looks like. Topics such as "customs, export, imports, dumping," "tariff, heading, customs, classification," and "vat, tax, taxable, supply" lend some support to Michal Bobek's claim that these dull subjects represent the normal life of EU law. ${ }^{35}$ Yet, topics like "employment, workers, pension, benefits," "residence, family, nationals, child," and "criminal, charter, penalty, penalties" suggest a more nuanced picture.

Similar to Table 2, Table 3 lists examples of cases heavily focused on a particular topic. The names of the parties involved suggest that the listed topics are, indeed, central to these rulings. The ruling most characteristic of the topic "criminal, charter, penalty, penalties," PPU Minister for Justice and Equality v Francis Lanigan (Case C-237/15), is a well-known urgent preliminary reference involving the Irish Ministry of Justice. Not unexpectedly, given the words defining the topic, the Grand Chamber ruling involves the interpretation of both the Framework Decision on the European Arrest Warrant and the Charter of Fundamental Rights and Freedoms of the

\footnotetext{
${ }^{35}$ See Bobek, supra note 15.
} 
Table 3. Cases with the largest topic proportion for a sample of judicial topics

\begin{tabular}{|c|c|c|c|}
\hline Topic & Case & Year & $\begin{array}{l}\text { Topic pro- } \\
\text { portion }\end{array}$ \\
\hline $\begin{array}{l}\text { tariff, heading, cus- } \\
\text { toms, classification }\end{array}$ & $\begin{array}{l}\text { Case 54/79 Firma Hako-Schuh Dietrich Bahner v Hauptzollamt of } \\
\text { Frankfurt am Main-Ost }\end{array}$ & 1979 & $98.88 \%$ \\
\hline $\begin{array}{l}\text { ohim, opposition, } \\
\text { registration, euipo }\end{array}$ & $\begin{array}{l}\text { Case T-144/10 Space Beach Club, SA v Office for Harmonisation in the } \\
\text { Internal Market (Trade Marks and Designs) (OHIM) }\end{array}$ & 2010 & $98.71 \%$ \\
\hline $\begin{array}{l}\text { restrictive, entities, } \\
\text { cfsp, funds }\end{array}$ & $\begin{array}{l}\text { Case T-43/12 Mohamad Hamcho and Hamcho International v Council } \\
\text { of the European Union }\end{array}$ & 2012 & $98.57 \%$ \\
\hline $\begin{array}{l}\text { tax, taxation, income, } \\
\text { resident }\end{array}$ & $\begin{array}{l}\text { Case C-35/11 Test Claimants in the FII Group Litigation v } \\
\text { Commissioners of Inland Revenue and The Commissioners for Her } \\
\text { Majesty's Revenue \& Customs }\end{array}$ & 2011 & $98.55 \%$ \\
\hline $\begin{array}{l}\text { health, product, } \\
\text { medicinal, authorisa- } \\
\text { tion }\end{array}$ & Case C-31/03 Pharmacia Italia SpA, formerly Pharmacia \& Upjohn SpA & 2003 & $98.51 \%$ \\
\hline $\begin{array}{l}\text { customs, export, } \\
\text { imports, dumping }\end{array}$ & Case C-34/14 A v Hauptzollamt Nürnberg & 2014 & $98.15 \%$ \\
\hline $\begin{array}{l}\text { criminal, charter, } \\
\text { penalty, penalties }\end{array}$ & Case C-237/15 PPU Minister for Justice and Equality v Francis Lanigan & 2015 & $97.50 \%$ \\
\hline $\begin{array}{l}\text { residence, family, } \\
\text { nationals, child }\end{array}$ & $\begin{array}{l}\text { Case C- } 480 / 08 \text { Maria Teixeira } v \text { London Borough of Lambeth and } \\
\text { Secretary of State for the Home Department }\end{array}$ & 2008 & $97.44 \%$ \\
\hline $\begin{array}{l}\text { vat, tax, taxable, sup- } \\
\text { ply }\end{array}$ & Case C-264/17 Harry Mensing v Finanzamt Hamm & 2017 & $97.31 \%$ \\
\hline $\begin{array}{l}\text { air, directives, transpo- } \\
\text { sition, transpose }\end{array}$ & Case C-359/17 Marcel Lutz and Others v TUIfly GmbH & 2017 & $92.35 \%$ \\
\hline $\begin{array}{l}\text { data, disclosure, per- } \\
\text { sonal, investigation }\end{array}$ & Case T-300/10 Internationaler Hilfsfonds v Commission & 2010 & $90.04 \%$ \\
\hline
\end{tabular}

European Union. Likewise, it should not be surprising Maria Teixeira $v$ London Borough of Lambeth and Secretary of State for the Home Department (Case C-480/08) involves the British Home Department given that it is the ruling most characteristic of the topic "residence, family, nationals, child."

Turning now to the CMLR corpus, Figure 6 depicts our "academic" topic model. In contrast to the legislative and judicial topic models, the CMLR topic model indicates considerably lower attention for CAP issues, but considerably more attention for constitutional matters. Except for one topic - "tariff, levy, sugar, quotas"-we do not find topics that clearly relate to agricultural commodities or CAP regulations and disputes. By contrast, several topics pertain to constitutional issues. One such topic is "ecthr, strasbourg, constitutions, vires." As shown in Table 4, the CMLR contribution most characteristic of this topic is Matthias Kumm's "Who is the Final Arbiter of Constitutionality in Europe?: Three Conceptions of the Relationship Between the German Federal Constitutional Court and the European Court of Justice." Table 4 confirms that the topic "conseil, etat, cour, cassation," too, can be interpreted as constitutional. The document containing the highest proportion of the topic is a 1974 article titled "How Supreme is Community Law in the National Courts?" by Gerhard Bebr. 


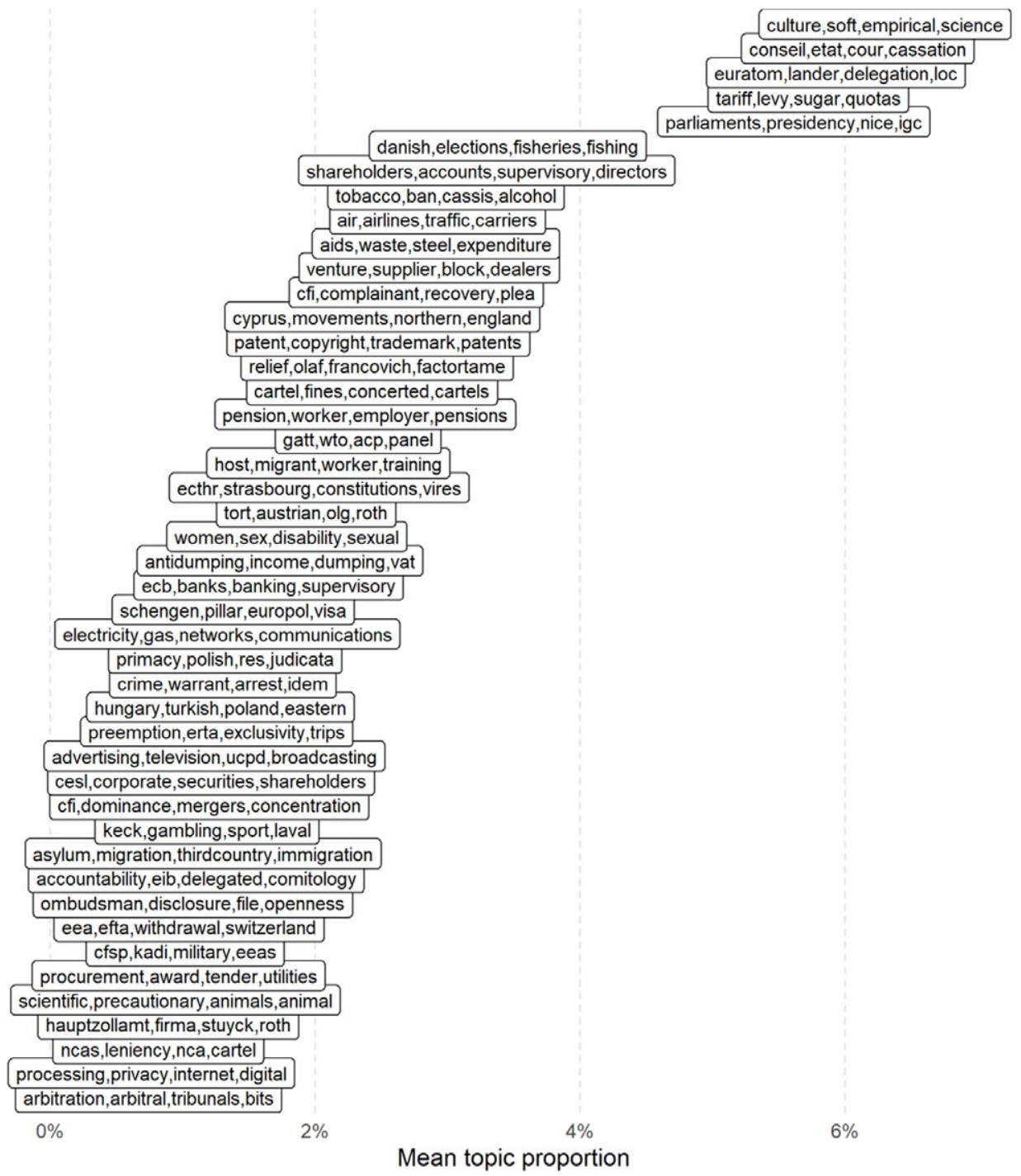

Figure 6. Topics and topic proportion in the CMLR sub-corpus (1963-2018).

Topics arguably constitutional in character further include "women, sex, disability, sexual" and "preemption, erta, exclusivity, trips." The topic "eea, efta, withdrawal, switzerland," which covers articles over Brexit-see Table 4-may also be seen as possessing a constitutional dimension, at least in the broad sense of the term.

Comparing the CMLR topic models with the legislative and judicial models appears to confirm the intuition that EU law scholars tend to focus more on what occurs at the CJEU stage than at the legislative stage. This seemingly buttresses the critique Rob Van Gestel and Hans Micklitz have leveled at "case law journalism." 36

So ingrained is the focus on court rulings that it might seem to follow naturally from the doctrinal method or from basic considerations of justiciability. However, not only do EU legislative texts spell out rules that are at least as important as those enunciated in judicial opinions, but only

\footnotetext{
${ }^{36}$ See van Gestel \& Micklitz, supra note 16, at 293.
} 
Table 4. Articles with largest topic proportion for a sample of CMLR topics

\begin{tabular}{|c|c|c|c|}
\hline Topic & Title of CLMR Article & Year & $\begin{array}{l}\text { Topic pro- } \\
\text { portion }\end{array}$ \\
\hline $\begin{array}{l}\text { preemption, erta, } \\
\text { exclusivity, trips }\end{array}$ & $\begin{array}{l}\text { 'Implied exclusive powers in the ECJ's Post-Lisbon jurisprudence: the } \\
\text { continued development of the ERTA doctrine' }\end{array}$ & 2018 & $99.84 \%$ \\
\hline $\begin{array}{l}\text { pension, worker, } \\
\text { employer, pensions }\end{array}$ & $\begin{array}{l}\text { 'Social security cases in the Court of Justice of the European } \\
\text { Communities' }\end{array}$ & 1982 & $99.82 \%$ \\
\hline $\begin{array}{l}\text { procurement, award, } \\
\text { tender, utilities }\end{array}$ & 'An assessment of the new legislative package on public procurement' & 2004 & $99.81 \%$ \\
\hline gatt, wto, acp, panel & $\begin{array}{l}\text { 'EC-ACP economic partnership agreements and WTO compatibility: An } \\
\text { experiment in north-south inter-regional agreements' }\end{array}$ & 2006 & $99.80 \%$ \\
\hline $\begin{array}{l}\text { tariff, levy, sugar, } \\
\text { quotas }\end{array}$ & 'The Agricultural Policy of the Community' & 1963 & $99.76 \%$ \\
\hline $\begin{array}{l}\text { women, sex, disabil- } \\
\text { ity, sexual }\end{array}$ & $\begin{array}{l}\text { 'Sex equality in the single market: New directions for the European } \\
\text { Court of Justice' }\end{array}$ & 1995 & $99.70 \%$ \\
\hline $\begin{array}{l}\text { eea, efta, withdrawal, } \\
\text { switzerland }\end{array}$ & $\begin{array}{l}\text { 'Brexit means Br(EEA)xit: The UK withdrawal from the. EU and its impli- } \\
\text { cations for the EEA' }\end{array}$ & 2018 & $99.69 \%$ \\
\hline $\begin{array}{l}\text { cfsp, kadi, military, } \\
\text { eeas }\end{array}$ & $\begin{array}{l}\text { 'The Meaning of Petersberg: Some Considerations on the Legal Scope of } \\
\text { ESDP Operations' }\end{array}$ & 2007 & $99.60 \%$ \\
\hline $\begin{array}{l}\text { processing, privacy, } \\
\text { internet, digital }\end{array}$ & 'Online service providers and liability: A plea for a balanced approach' & 2011 & $99.54 \%$ \\
\hline $\begin{array}{l}\text { ecthr, strasbourg, } \\
\text { constitutions, vires }\end{array}$ & $\begin{array}{l}\text { 'Who is the Final Arbiter of Constitutionality in Europe?: Three } \\
\text { Conceptions of the Relationship Between the German Federal } \\
\text { Constitutional Court and the European Court of Justice' }\end{array}$ & 1999 & $99.21 \%$ \\
\hline $\begin{array}{l}\text { conseil, etat, cour, } \\
\text { cassation }\end{array}$ & 'How Supreme is Community Law in the National Courts?' & 1974 & $99.76 \%$ \\
\hline
\end{tabular}

a small fraction of those are ever litigated before the CJEU. Justiciability alone cannot explain the inordinate emphasis on CJEU rulings. In fact, as legislative scholars, like Rob van Gestel have insisted, there is no reason inherent to the doctrinal approach to concentrate exclusively on legal developments at the judicial stage.

Rather than methodological precepts or dictates of justiciability, this pattern points to the existence of discussion cycles heavily influenced by the CJEU's agenda. Both CMLR editors and academic writers prioritize the themes that the CJEU has put in the discussion cycle. The reasonable presumption that a manuscript addressing a topic in the current discussion cycle stands a better chance of being accepted, may work to further reinforce this dynamic. As we shall see, the diachronic analysis we present below is also consistent with this analysis.

Zooming in on differences between judges and academics, the latter exhibit a greater predilection for sexier constitutional topics. This relative divergence echoes the critique of Michal Bobek. To be sure, academic contributions devoted to the CAP or to public procurement-captured by the judicial topic "procurement, award, tender, utilities"—-do exist. ${ }^{37}$ Yet these topics seem less prevalent in academic than in judicial discourse. This pattern may, in part, reflect editorial policy.

\footnotetext{
${ }^{37}$ The work of Francis Snyder, however, deserves mention. See, e.g., FranCIS G SNYder, LAW OF THE COMMON Agricultural Policy (1985); Francis G. Snyder, The Special Legal Status of Agriculture: Assumptions and Contradictions in Economic Law, New Directions in European Community law (1990); Francis Snyder, The Common Agricultural Policy in the Single European Market, Academy of European law, Collected Courses of the Academy of European law (1992); Francis Snyder, The Use of Legal Acts in EC Agricultural Policy, Sources and Categories of European Union law: A Comparative and Reform Perspective (1996);); Francis Snyder, 'CAP' The Oxford Handbook of the European Union (2012); Francis Snyder \& Ahmed
} 


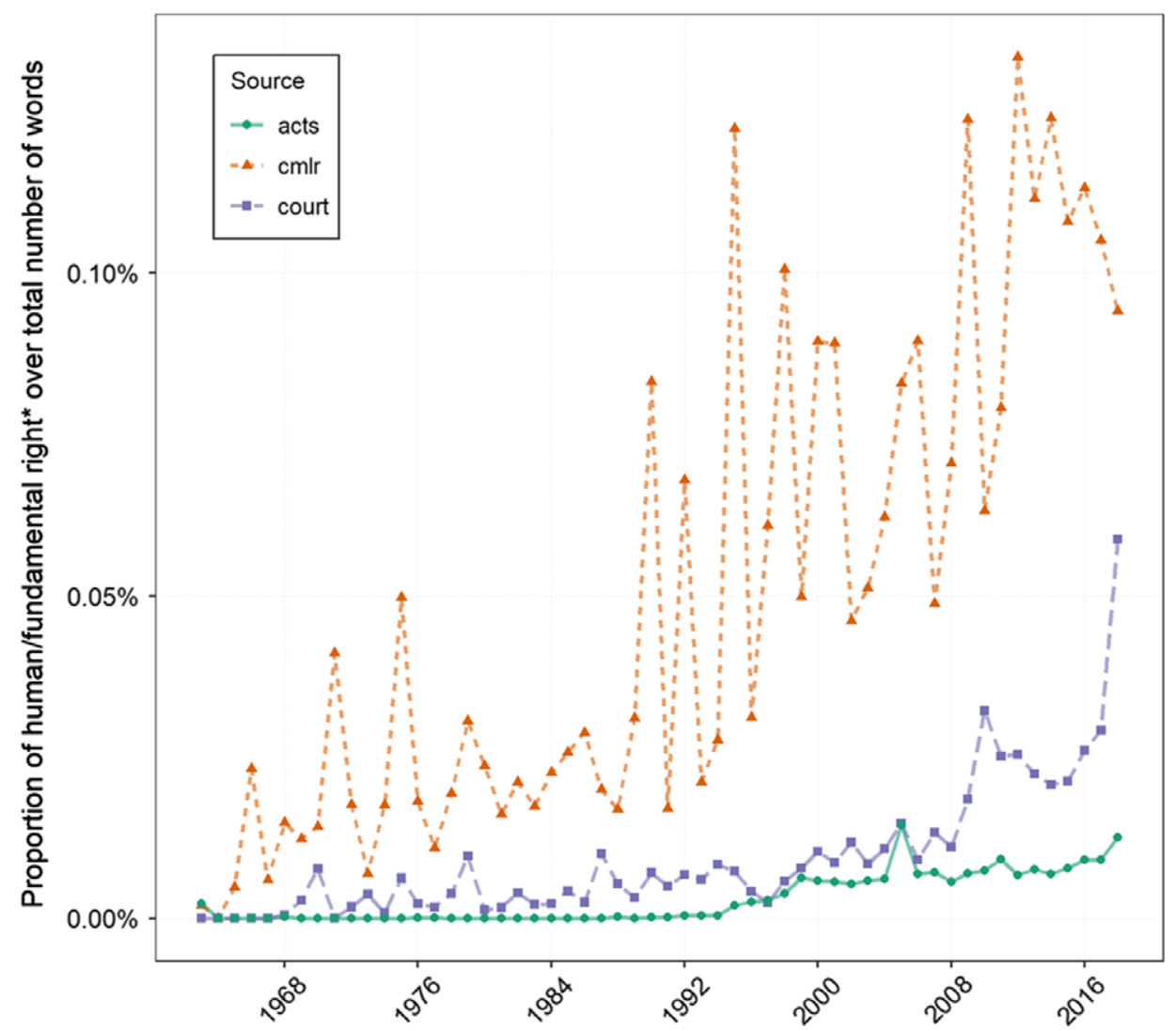

Figure 7. Relative frequency of the phrase human/fundamental rights in the three sub-corpora.

As its name implies, the CMLR was originally meant to focus on the construction of the internal market. But the personal predilections of academic writers represent a significant factor, too.

Interestingly, the article most representative of the sole academic topic presenting a real connection with the CAP_- "tariff, levy, sugar, quotas" - is penned by a European Commission official—see Table 4. "The Agricultural Policy of the Community" was published in 1963 by Giancarlo Olmi, who worked for the European Commission's legal service. While ascertaining the affiliation of CMLR contributors is beyond the scope of the present Article, this finding is consistent with what we said above about the impact of overlap in personnel on the focus of EU law scholarship. As Harm Schepel and Rein Wesseling have demonstrated, albeit on the basis of a smaller corpus, many CMLR contributors have links to EU institutions. ${ }^{38}$

\section{Temporal Variations}

Figure 7 is another illustration of the points we just made about the focus of EU legal scholarship. The plot depicts the relative proportion of the phrase "human/fundamental rights" across the three sub-corpora over time. Although legislators, judges, and academics have all been giving

Mahiou, la Sécurité Alimentaire/Food Security and Food Safety (Centre for Studies and Research in International Law ed., 2006). See Burrel, supra note 17.

${ }^{38}$ See Schepel and Wesseling supra note 25 . For a recent illustration (by no other than the CJEU's president) see 

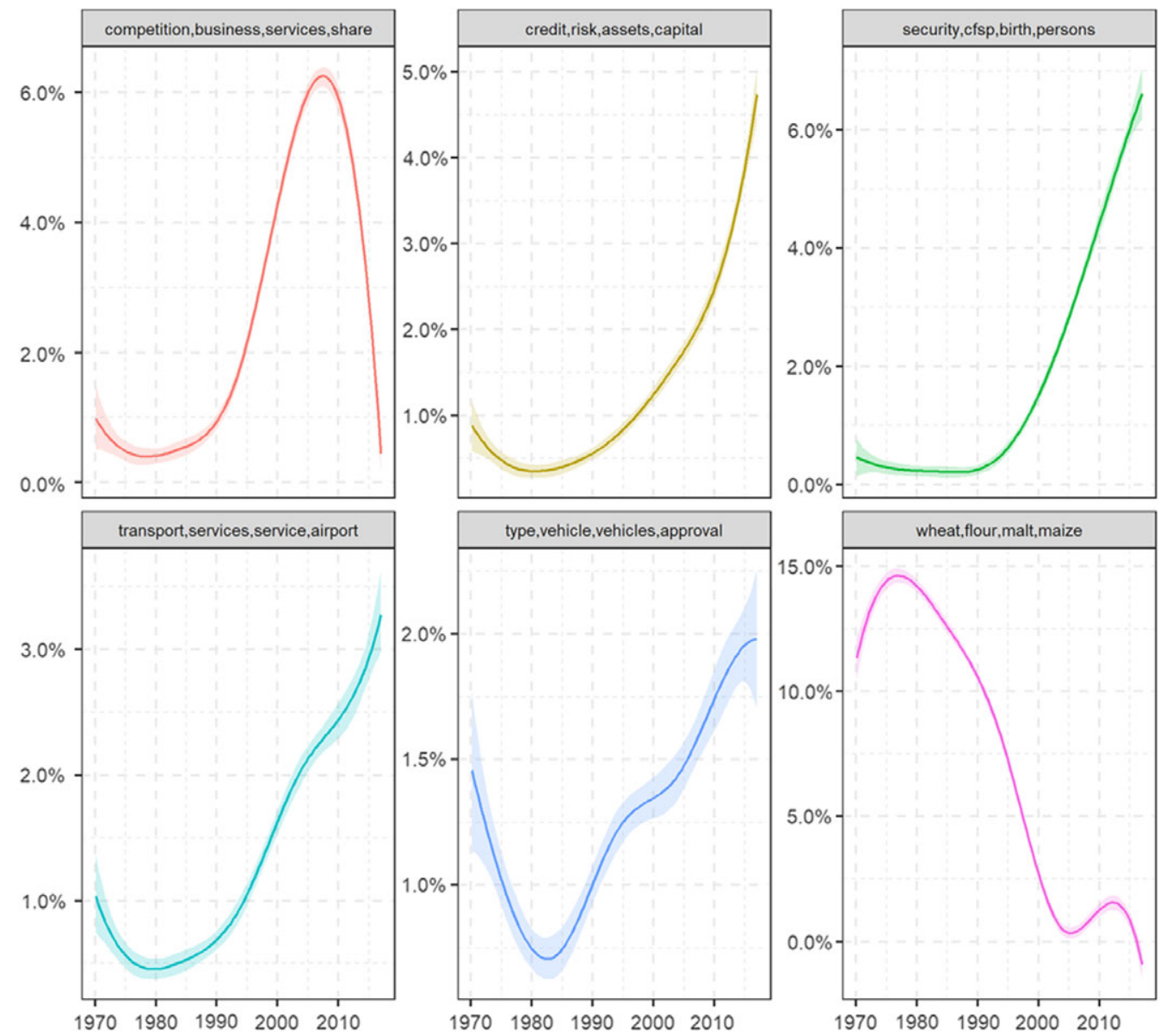

Figure 8. Topic proportion over time for selected legislative topics.

greater attention to fundamental rights, the emphasis on rights is clearly, and consistently stronger in academic writings. Consistent with our concept of co-evolution, the three discourses have, to a noticeable extent, developed along similar upward trajectories, but with diverging growth rates.

The plot shows a clear increase in attention to human/fundamental rights coinciding with the adoption of the Lisbon Treaty in both the judicial, and CMLR sub-corpora, plausibly as a consequence of the entry into force of the Charter of Fundamental Rights, and the obligation for the EU to accede to the European Convention on Human Rights, Article 6(2) TEU.

As the issue of human rights illustrates, topic attention may undergo substantial shifts over time. For reasons of space, we do not report time trends for all topics, and reserve them for the Appendix. Instead, we focus on a selection of legislative, judicial, and CMLR topics that illustrate shifts which we judged to be substantively important. These are depicted in Figures 8, 9, and 10 , where shaded bands around the curves indicate how certain the model is about the true topic proportion.

As a cursory look at the three figures makes plain, shaded bands are larger for CMLR topics because the topic model is constructed from a smaller number of documents. Fewer documents mean less information to adjust the topic model to the corpus, and therefore, more uncertainty 


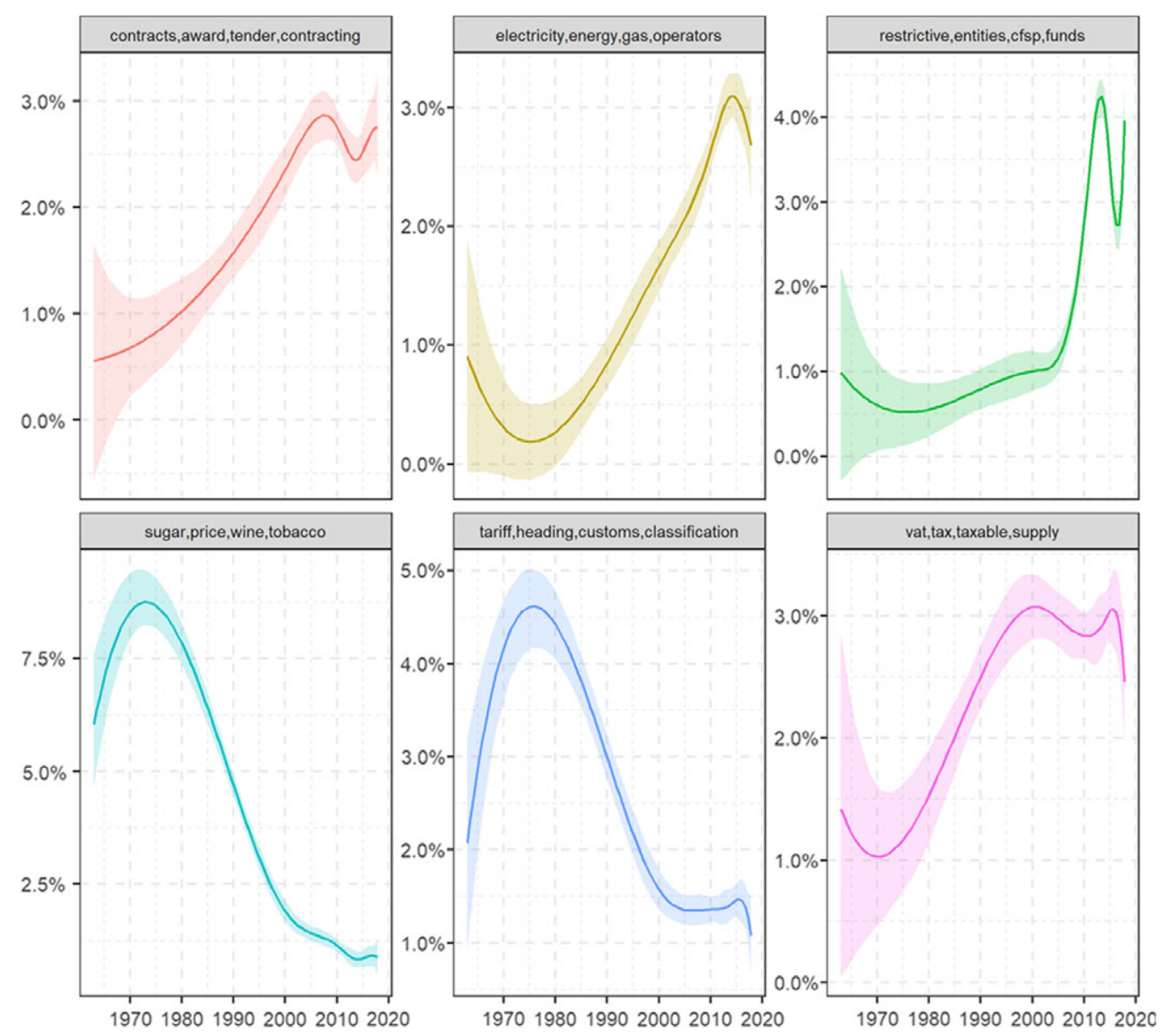

Figure 9. Topic proportion over time for selected CJEU topics.

over topic proportion. Similarly, confidence bands for the CJEU and legislative topics are larger in the early years, reflecting lower judicial, and legislative output in those years.

More substantively, some of the downward and upward trends in Figures 8 and 9 are illustrative of the evolution of single market economic regulation. Legislation has become less about agricultural commodities - as exemplified by the declining share of "wheat, flour, malt, maize" — and more about free movement of capital- "credit, risk, assets, capital"-, the liberalization of transport markets - "transport, services, service, airport" —,and the harmonization of safety standards- "type, vehicle, vehicles, approval." Likewise, Figure 9 shows that attention to tariffs and farming issues has decreased, while the proportion of cases dealing with taxation, public procurement, and energy markets has gone up. These dynamics appear to reflect distinct phases of the construction of the single market, with the early phase focusing more on the removal of tariff barriers and the establishment of a customs union and later phases focusing on deeper regulatory obstacles to the free movement of services, products and capital, and the liberalization of utility and transport markets. ${ }^{39}$ The upward slope for the topic "credit, risk, assets, capital" in Figure 8, in

\footnotetext{
${ }^{39}$ Neil Kinnock, The Liberalisation of the European Aviation Industry, 8 EuR. Bus. J. 8 (1996); Tooraj Jamasb \& Michael Pollitt, Electricity Market Reform in the European Union: Review of Progress toward Liberalization \& Integration, 26 ENERGY J. (2005).
} 

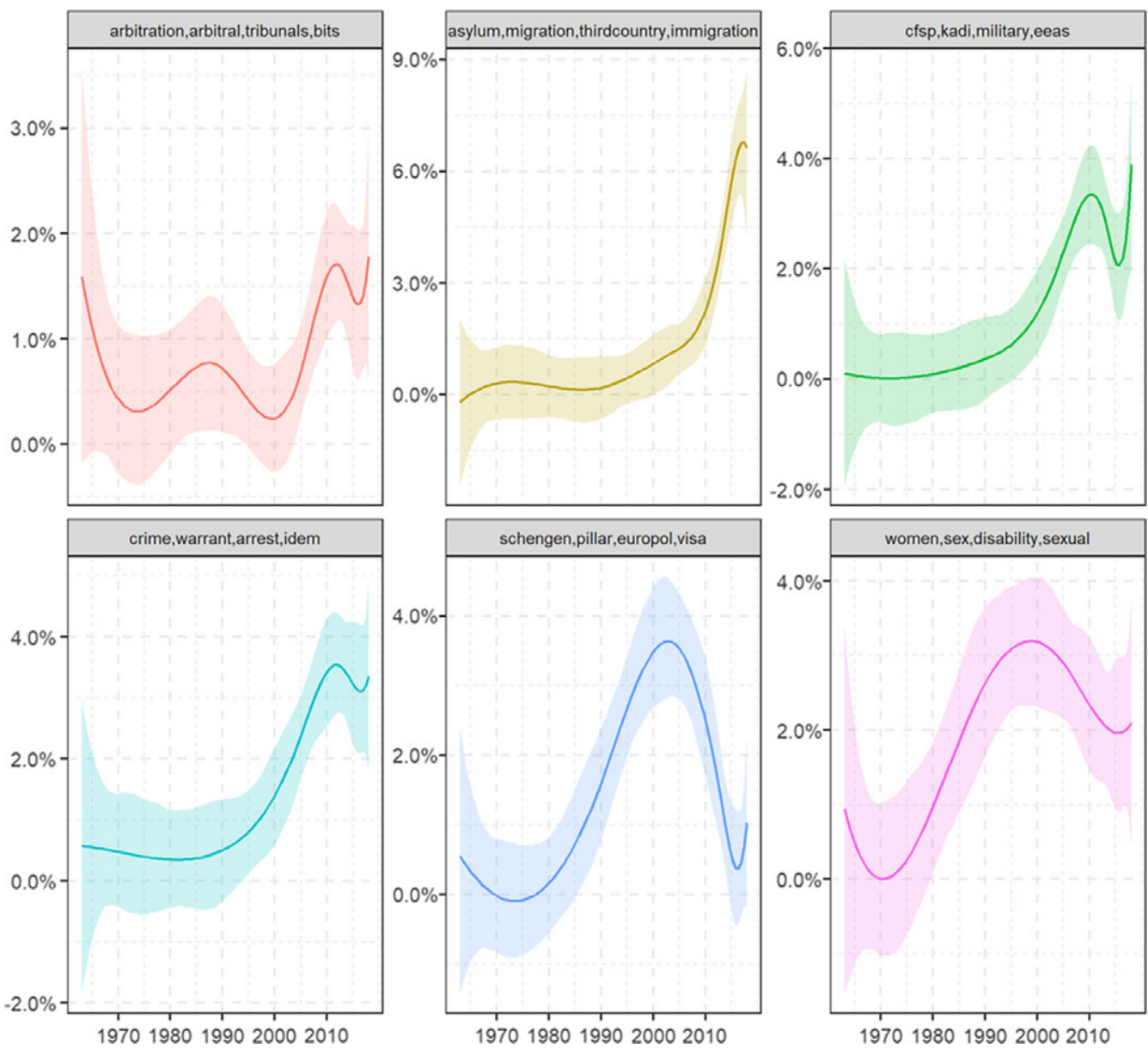

Figure 10. Topic proportion over time for selected CMLR topics.

particular, seems to reflect legislative efforts, at the end of the 1990s, to make the free movement of capital an economic and legal reality. ${ }^{40}$ The temporal trends for these topics along with those reported in the Appendix suggest that, as far as legislators and judges are concerned, economic integration and the homo economicus continue to occupy centre stage, although the emphasis has shifted from "old" issues, for example, tariffs and farming, to "new" issues, for example, transport, energy, taxation, technical standards.

The trends for topic "security, cfsp, birth, persons" in Figure 8, topic "restrictive, entities, cfsp, funds" in Figure 9 and topic "cfsp, kadi, military, eeas" in Figure 10 all point to an increase in attention to security and foreign policy issues around 2000. Before that mark topic proportion is zero or close to zero. The curves in the judicial and CMLR topic models even display similar shapes.

Less surprising is the increase in attention to immigration-topic "asylum, migration, third country, immigration" in Figure 10-and criminal matters- "crime, arrest, warrant, idem"in CMLR articles. Interest in these topics is relatively new. Interests in criminal procedure can

\footnotetext{
${ }^{40}$ Leo Flynn, Coming of Age: The Free Movement of Capital Case Law 1993-2002, 39 Common Mkt. L. REv. 773 (2002).
} 
be linked to the legislative act introducing the European Arrest Warrant and the relatively large number of CJEU cases it has spawned. ${ }^{41}$ The CJEU's case law on citizenship and immigration is also of recent origin. ${ }^{42}$ Discrimination- "women, sex, disability, sexual" — by contrast, has been an established topic in EU legal scholarship for somewhat longer, which, again, reflects the temporal evolution of the CJEU's case law. ${ }^{43}$

While academics do not cover each and every CJEU ruling, our diachronic analysis suggests that the CJEU is, nonetheless, the most influential voice in the discussion cycle. CJEU rulings largely dictate when topics enter and exit the discussion cycle.

\section{E. Conclusion}

In this Article, we explored a novel, giant corpus of EU law texts using computer-based text-mining techniques. The aim of our analysis was to measure and compare issue attention in legislative, judicial, and academic texts at a relatively high level of generality. Overall, our text analytics cast light on areas of both convergence and divergence, in line with the notion of co-evolution which we suggested as a way to conceptualize relations among the three domains.

We found that, on the whole, there is a greater overlap between the judicial and the legislative voice and between the judicial and the academic than between the academic and the legislative. Academics respond more to CJEU rulings than to legislative enactments, which implies that there might be a grain of truth in the "case law journalism" critique levelled at EU law scholarship. From our analysis, legal scholars also look more inclined to shun the technical, regulatory stuff that forms the bread and butter of legislation and, to a large degree, of CJEU adjudication. The daily life of EU law, as some have put it, is indeed, more often than not about dull, unexciting matters such as VAT, tariff nomenclatures, and agricultural commodities.

As EU law scholars' attention tends to be skewed towards constitutional and fundamental rights topics, a reader leafing through contributions in a law journal like CMLR might get the impression that EU law has moved away from businessmen's Europe more than it really has. According to our textual analysis, EU positive law continues to mostly concern itself with the

\footnotetext{
${ }^{41}$ The first case decided under the European Arrest Warrant is C-303/05, Advocaten voor de Wereld, issued in 2007. Until the end of 2018, there were 33 cases decided by the Court on the topic. For the overview of the cases, see Eurojust, 2018 Overview on the Case Law of the Court of Justice of the European Union (CJEU) on the European Arrest Warrant (EAW), https://www.eurojust.europa.eu/case-law-court-justice-european-union-european-arrest-warrant; Anne Pieter van der Mei, The European Arrest Warrant System: Recent Developments in the Case Law of the Court of Justice, 24 MAASTRICHT J. Eur. CoMP. L. 882 (2017); Luisa Marin, Effective and Legitimate?: Learning from the Lessons of 10 Years of Practice with the European Arrest Warrant, 5 NEw J. EUR. CRIM. L. 327 (2014).

${ }^{42}$ The earliest case decided on the issue of EU citizenship dates from 2008 and concerns the Regulation 343/2003 on establishing the criteria and mechanisms for determining the Member State responsible for examining an asylum application. See Case C-19/08 Migrationsverket v Edgar Petrosian, 2009 E.C.R. No. 343/2003, https://curia.europa.eu/juris/liste.jsf? language $=$ en\&jur $=\mathrm{C}, \mathrm{T}, \mathrm{F} \&$ num $=\mathrm{c}-19 / 08$. Prof Dr Gerard-René de Groot and Ngo Chun Luk, Twenty Years of CJEU Jurisprudence on Citizenship, 15 German L.J. 821 (2014); Camelia Toader \& Andrei I Florea, Free Movement of Workers and the European Citizenship Studies and Articles, 2012 Revista Română de Drept European 67 (2012); Willem Maas, The Origins, Evolution, and Political Objectives of EU Citizenship, 15 German L. J. 797 (2014); Susanne K Schmidt, Judicial Europeanisation: The Case of Zambrano in Ireland, 37 WEST EUR. POL. 769 (2014); Francesca Ippolito, Migration and Asylum Cases before the Court of Justice of the European Union: Putting the Eu Charter of Fundamental Rights to Test?, 17 Eur. J. Migration \& L. 1 (2015).

${ }^{43}$ European Union Agency for Fundamental Rights, Handbook on European Non-Discrimination Law (2018 ed.); Evelyn Ellis, European Community Sex Equality Law, Clarendon Press, Oxford University Press (1991); Sonia Mazey, Gender Mainstreaming in the EU: Principles and Practice, Kogan Page (2001); Evelyn Ellis \& Philippa Watson, EU Anti-Discrimination Law, OUP Oxford (2012); See Craig \& de Búrca supra note 14; Claire Kilpatrick, Gender Equality: A Fundamental Dialogue' in Silvana Sciarra (ed), Labour law in the courts: National Judges And The European Court of Justice, Hart Pub (2001); Claire Kilpatrick, The Court of Justice and Labour Law in 2010: A New EU Discrimination Law Architecture, 40 INDUS. L. J. 280 (2011).
} 
regulation of economic activity, although the focus of market regulation has shifted somewhat, away from farming commodities and custom duties and towards capital flows, taxation, and safety standards. On the one hand, while attention to fundamental rights in legislation and CJEU rulings seems to have increased in recent years, it is far from being central to the agenda of judges and legislators. On the other hand, the discrepancy in focus between legal scholarship and legislation and case law is something that one may put to the academics' credit. Indeed, it can be argued that it is the responsibility of legal scholars to take fundamental rights and constitutional issues seriously when judges and legislators are perceived to fail their duty.

In any case, the analysis presented in this Article was conceived as primarily exploratory and descriptive, and we did not purport to adjudicate these questions. While the methodological approach we adopted is indubitably unconventional, at least for a legal audience, recent contributions have presented corpus linguistics and text-mining techniques as providing a new methodological paradigm for European legal research. ${ }^{44}$ Although we certainly see room for further refinements of our findings, we hope we have demonstrated what such methods can achieve in terms of uncovering patterns and dynamics in large collections of EU legal texts.

\footnotetext{
${ }^{44}$ Urska Sadl and Henrik Palmer Olsen, Can Quantitative Methods Complement Doctrinal Legal Studies? Using Citation Network and Corpus Linguistic Analysis to Understand International Courts, 30 LeIDEN J. INT'L L. 327 (2017); Arthur Dyevre, Wessel Wijtvliet \& Nicolas Lampach, The Future of European Legal Scholarship: Empirical Jurisprudence, 26 MAASTRICHT J. EUR. COMP. L. 348 (2019).
} 


\section{F. Appendix}
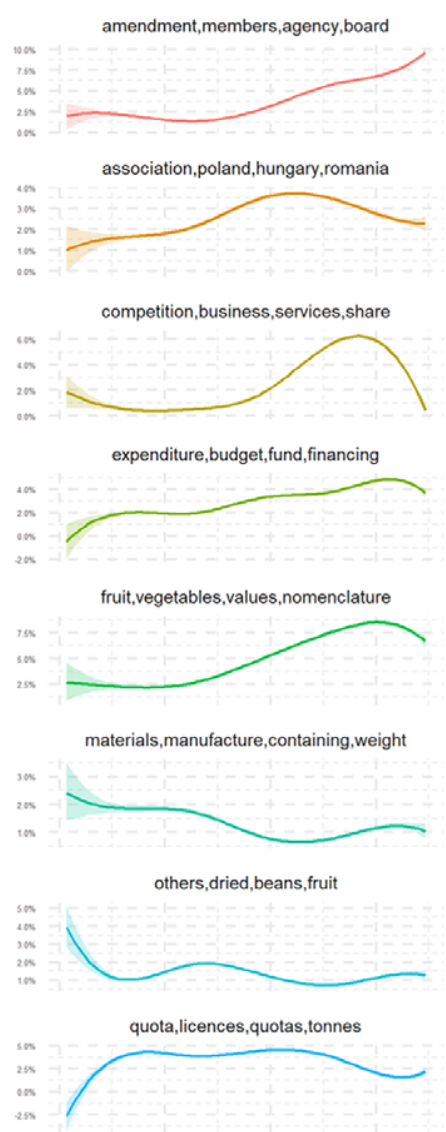

security,cfsp, birth, persons

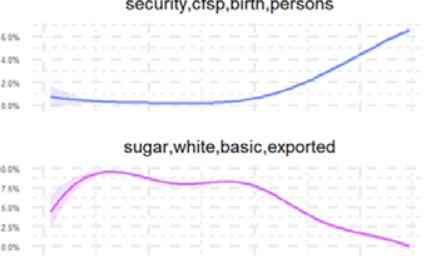

transport,services,service,airport
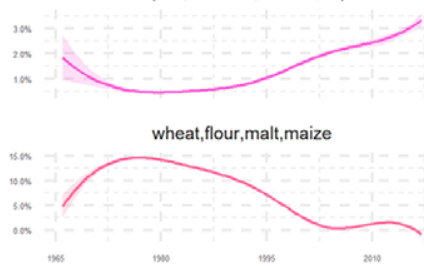

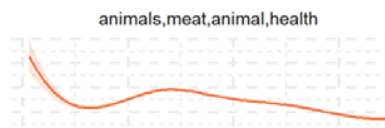

authority,rights,services,access

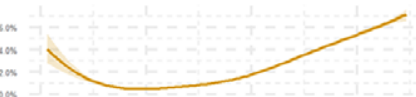

credit,risk,assets,capita

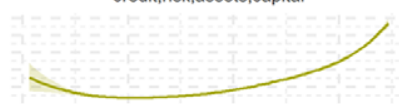

fishing,vessels,vessel,fisheries

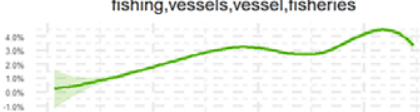

industry,dumping,producers, investigation

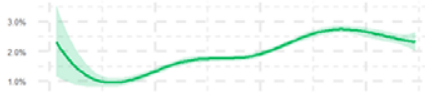

million,measure,restructuring,scheme

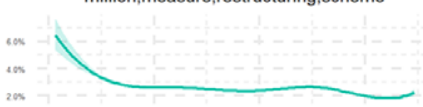

programme,research,support,cooperation
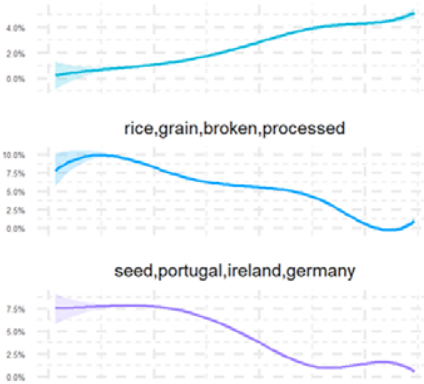

tender intervention, invitation,tenders

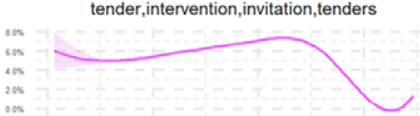

type,vehicle,vehicles,approval

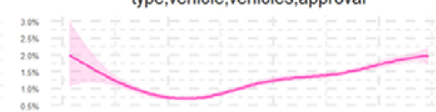

wine,producers,areas,producer

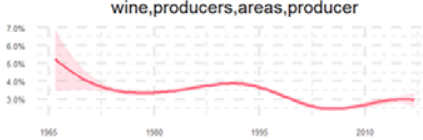

appropriations,expenditure,staff,revenue
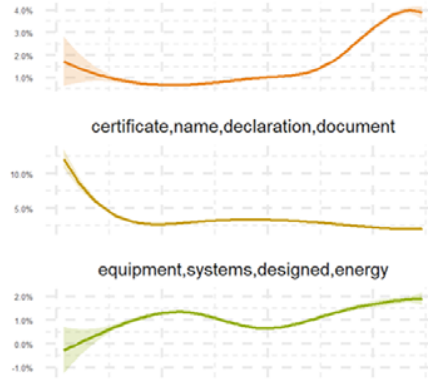

food,substances,substance,plant
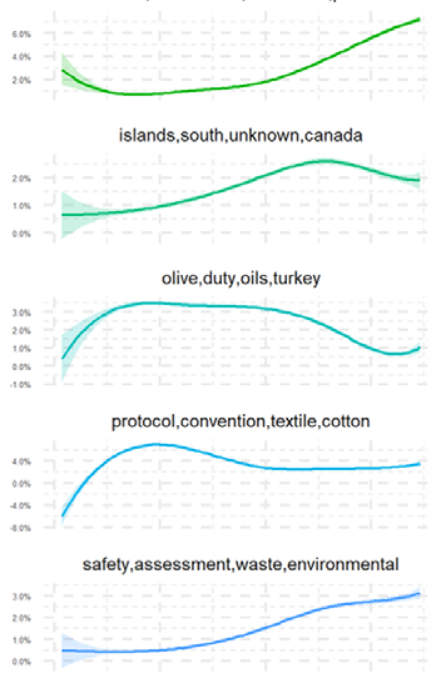

services,social, insurance,persons

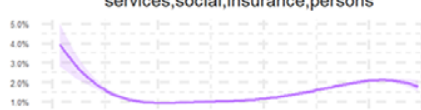

test,acid,water,method

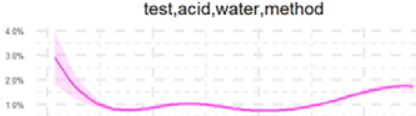

weight,exceeding,milk,matter

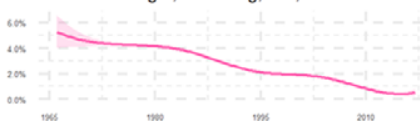

Figure A1. Topic proportion over time for legislative topics. 
advertising,television, copyright, broadcasting

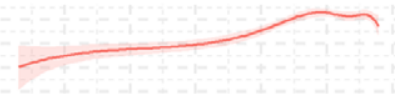

appellant,appellants,unfounded,aside

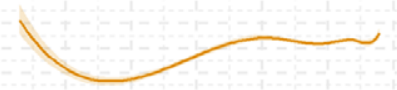

body,management,association, bodies

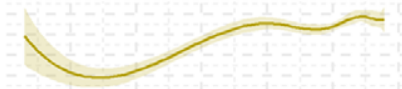

criminal,charter,penalty,penalties

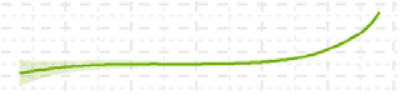

data,disclosure,personal, investigation

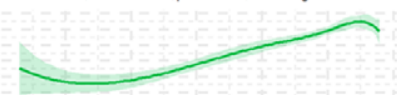

eur,assistance,greek,project

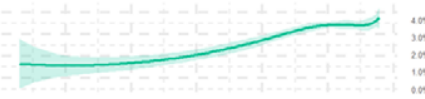

ireland,accession,fishing,poland

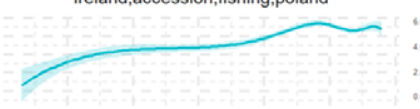

price,prices,agreements,sales

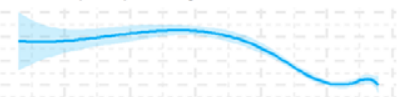

residence,family,nationals,child

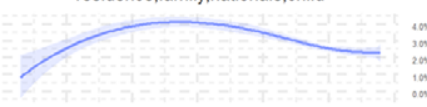

staff,officials,post,committee

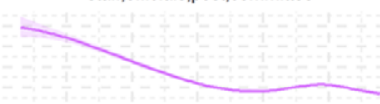

tax, taxation, income,resident

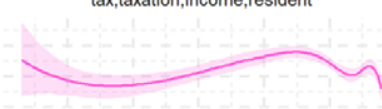

vat,tax,taxable,supply

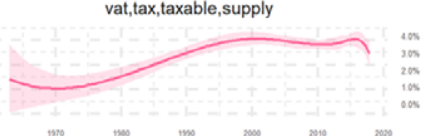

aid, restructuring,ecsc, million

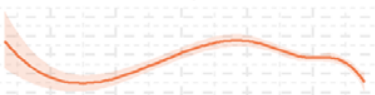

austria,prohibition, portuguese,austrian

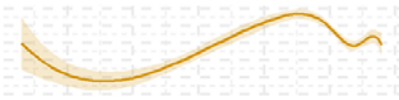

contracts,award,tender,contracting

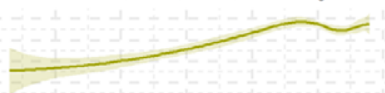

customs,export,imports,dumping

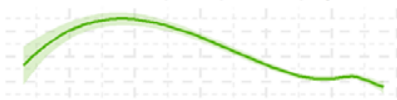

electricity,energy,gas,operators

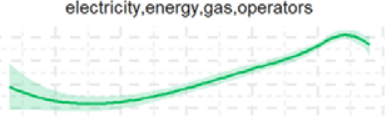

fine,cartel,fines,objections

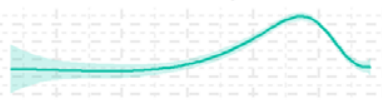

milk,agricultural,quota,levy

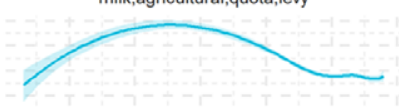

product,technical,packaging,equipment

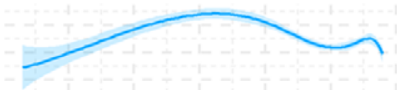

restrictive,entities,cfsp,funds

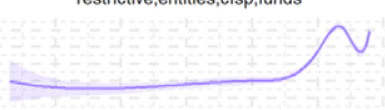

sugar,price,wine,tobacco

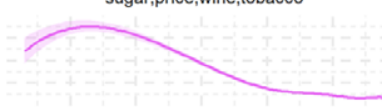

transfer,consumer,capital,credit

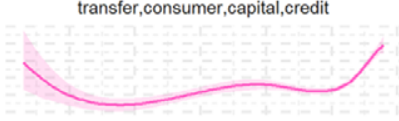

waste,environmental,environment,water

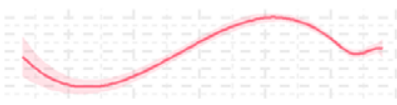

Figure A2. Topic proportion over time for CJEU topics. 

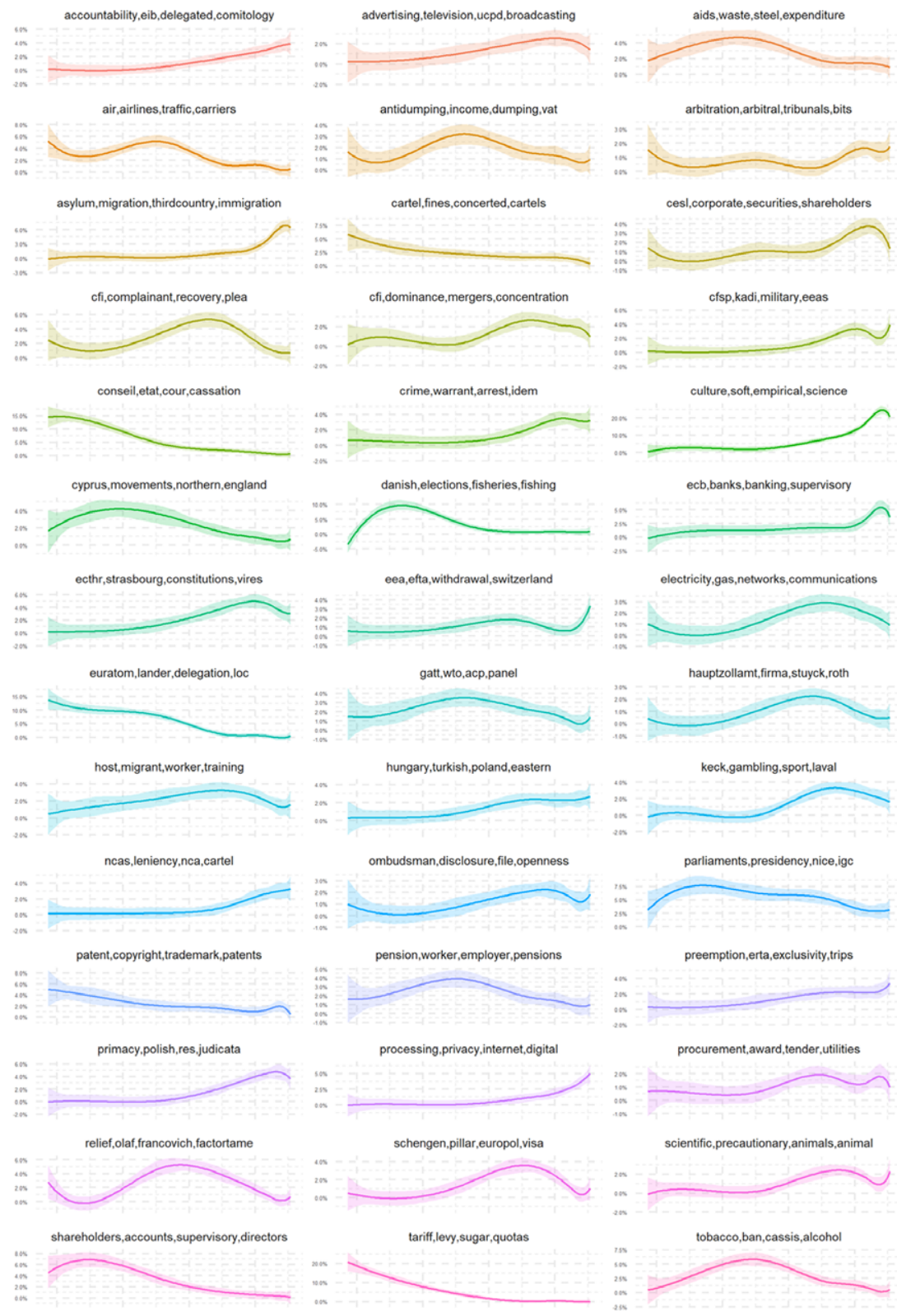

tort,austrian,olg,roth
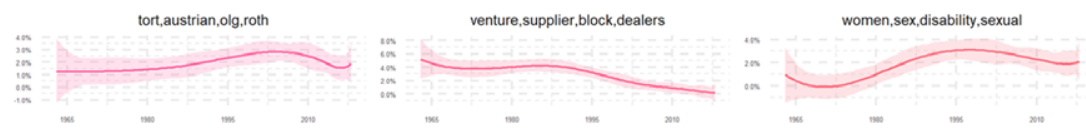

Figure A3. Topic proportion over time for CMLR topics.

Cite this article: Dyevre A, Glavina M, and Ovádek M (2021). The Voices of European Law: Legislators, Judges and Law Professors. German Law Journal 22, 956-982. https://doi.org/10.1017/glj.2021.47 